\title{
JOST 921FR
}

\section{EVALUATING THE NET EFFECTS OF ECOTOURISM ON THE ENVIRONMENT: A FRAMEWORK, FIRST ASSESSMENT AND FUTURE RESEARCH}

\section{INTRODUCTION}

Ecotourism has now been debated in theory, and attempted in practice, for at least two decades. Definitions differ in detail (Buckley, 2009; Donohoe \& Needham, 2006; Weaver \& Lawton, 2007) but all agree that ecotourism is a practical as well as theoretical construct. Its aims are to change real-world operations in the tourism industry, as well as improving our understanding of tourism as a social phenomenon. Have these aims been achieved, or are we at least moving towards them, and how can we tell? There does not seem to be any previous attempt to address this issue. The analysis of academic ecotourism literature carried out by Weaver and Lawton (2007), for example, specifically excluded any attempt to evaluate its practical achievements or outcomes. This contribution proposes an analytic framework for such an endeavour, assesses available data as far as possible, and endeavours to identify the research required to improve future evaluations.

Such an evaluation has theoretical significance for the academic analysis of tourism more broadly. Ecotourism may be viewed as an intervention in the tourism industry: an attempt to modify its mode of operation for reasons not entirely commercial. In the words of Black and Crabtree (2007, p. xxvii), ecotourism is "a force within the industry that, in its very essence, aims to minimise tourism's negative impacts whilst maximising tourism's positive impacts". Whilst smaller in scale than external effects such as energy prices and terrorism, ecotourism represents a relatively large internal intervention in the global tourism industry, and one which has now been continued for an extended period. This provides analytical opportunities from the perspectives of tourism policy and tourism entrepreneurship. In addition, any framework for analysing progress in ecotourism may also be relevant to measuring the sustainability of tourism more broadly, which is still a contested area of research (Bramwell \& Lane, 2008; Gössling et al., 2008, 2009).

To measure progress towards goals we must first specify the goals under consideration. A variety of social, economic and environmental aims have been proposed for ecotourism, some with general agreement and others less so. Here, therefore, I focus only on one generally agreed goal of ecotourism, included routinely in published definitions and indeed the original reason for the prefix "eco" - namely, to improve environmental outcomes in some way.

Different definitions include other more descriptive environmental components, such as nature-based products or settings (Newsome et al., 2002; Vereczi, 2007; Weaver \& Lawton, 2007) but this is not in itself a goal. Social goals such as the alleviation of poverty, the involvement of local communities, and the preservation of pride in traditional cultures are also referred to repeatedly, sometimes within ecotourism itself and sometimes as community tourism, community ecotourism or responsible tourism (Spenceley, 2008a). Progress towards these goals may also be an important measure of ecotourism, but is not considered here. Private-sector ecotourism enterprises must 
necessarily also have financial goals, such as cashflow, profitability, and return on investment, but these are essentially similar to tourism enterprises more generally (McKercher, 1998). The framework proposed here, therefore, refers only to environmental goals.

\section{METHODS AND DATA SOURCES}

There is a very extensive literature, largely theoretical, about what the environmental goals of ecotourism should be and what mechanisms might be used to achieve them (Weaver \& Lawton, 2007). There is a rather more limited literature, reviewed here, on the application of these mechanisms in real-world examples, and how successful they have been. There is also an extensive literature, much of it practical, about what environmental impacts ecotourism produces at individual sites (Buckley, 2004a; Liddle, 1997); and a more theoretical literature on what negative impacts it could produce more broadly, through indirect mechanisms involving political processes.

For the framework proposed here, a list of potential mechanisms, expressed at an aggregate or general level applicable across the entire ecotourism industry, was compiled (Table 1). It is divided into four components: mechanisms which aim to create positive environmental outcomes; those which aim to reduce negative environmental outcomes; those which create negative environmental outcomes; and those which remain controversial, such as scale and mainstreaming. Included in this last category are indirect mechanisms where social outcomes may influence environmental outcomes.

This list necessarily reflects a degree of subjective judgment as to how these potential mechanisms are expressed and classified. It is a mixed-criterion classification, a classification of convenience. The boundaries between these categories are not necessarily hard and fast; each of the mechanisms listed could be subdivided indefinitely. Entire books have been written about visitor management in protected areas, included here under the generic category of behaviour management tools. The same applies to environmental design, included here as a sub-category of environmental management technologies; and to tour guiding, included here only as part of education and interpretation. The various mechanisms listed in Table 1 also involve different combinations of stakeholders: commercial tour operators, commercial tour clients, government agencies, industry associations, independent travellers, landholders and others. Since the classification in Table 1 is constructed specifically to evaluate environmental outcomes, and relatively little of the literature itself follows this approach, relevant publications are not necessarily labelled in the same way as in Table 1. The table therefore also shows associated terms used within the tourism literature and associated fields of study in the broader grey and academic literature

Recent reviews cite over 1000 publications on various aspects of ecotourism (Buckley, 2009; Weaver, 2008). Little of this literature, however, analyses individual commercial ecotourism products and their environmental outcomes. From over two dozen books in related areas published in the past five years, only a few include case studies of this type (Table 2). An analysis by Kruger (2005), purportedly using 188 published examples of ecotourism, did not list the products examined or the data used in analysis, and is hence of limited value. For some of the mechanisms listed in Table 1, additional data are available in the literatures of: community and responsible tourism (Spenceley, 2008a); 
nature-based tourism (Newsome et al., 2002); sustainable tourism (Stabler, 1997; Weaver, 2006); parks and outdoor recreation (Bushell \& Eagles, 2007; Manning, 2007; Pigram \& Jenkins, 2006); wilderness and protected-area management (Hendee \& Dawson, 2002; Lockwood et al., 2006); ecocertification (Black \& Crabtree, 2007; Font and Buckley, 2001); tourism and climate change (Becken \& Hay, 2007; Hall \& Higham, 2005); or tourism in particular geographical regions (e.g. Gössling \& Hultman, 2006; Snyder \& Stonehouse, 2007; Stronza \& Durham, 2008) or terrain types (e.g. Cater \& Cater, 2007; Godde et al., 2000; Higham \& Luck, 2008; Prideaux \& Cooper, 2009).

Available data differ greatly in relevance and reliability. Rigorous evaluation of environmental outcomes from commercial ecotourism products generally requires on-site audit with full access, internal and external documentary sources, and interviews with staff and third-party stakeholders; and even then there is no guarantee that the auditor has uncovered everything relevant. Many authors focus on place or management rather than companies or products, and do not distinguish between independent travellers and escorted tour clients. This applies particularly to the literature of parks and recreation management. Much of the literature is relatively uncritical. The same case studies are cited by successive authors, and achieve recognition simply through repetition, even if the original reference was actually written by a staff member, consultant or close associate of the organisation concerned (e.g. Nycander, 2002; Shah, 2002). In some cases the original material may have been simply a contribution to an unrefereed compilation; or a report with no pretensions to academic credibility; or an article which, though scholarly in itself, was not intended to test the claims or examine the achievements of the ecotourism enterprise concerned. Such sources may still be accurate, but they are less reliable. In addition, many authors continue to cite older descriptions of particular case studies without the caveat that they may no longer be valid. Small businesses can change quickly, in ecotourism as in other sectors; community enterprises can collapse, and donor-funded projects may not survive independently. The results presented in the following sections are thus tempered with a degree of uncertainty over data.

\section{GENERATING POSITIVE EFFECTS}

\section{Introduction}

Mechanisms by which ecotourism could generate positive environmental effects for the natural environment are listed in Table 3, in five main categories: environmental activism; support for environmental NGOs; contributions to public protected area management agencies; contributions to community conservation efforts; and support for private conservation reserves. These categories are reviewed in turn below. Lists of examples, where available, are intended to be representative rather than exhaustive.

\section{Political Mechanisms}

The most significant potential mechanism for ecotourism to generate net positive outcomes for the natural environment is if it can favourably influence whole-of-government national or state policies towards parks and conservation, including legislation, land tenure, staffing and budgets. Perhaps paradoxically, as a large-scale political process this mechanism is also the hardest to evaluate. 
Madagascar provides an example (Pawliczek \& Mehta, 2008). Since 1992 its parks have been run by an NGO-style organisation established by government decree: l'Association Nationale pour la Gestion des Aires Protegees, ANGAP (The National Association for the Management of Protected Areas in Madagascar). This seems to have been established following several decades' efforts by conservation NGOs. The ANGAP website (ANGAP-PNM, 2009), however, has apparently not been updated since 2005. According to that website, $50 \%$ of park entry fees are used for local community development projects in areas around the parks. These fees are derived largely from international tourists who visit Madagascar's national parks, largely with commercial tour operators, to look at lemurs, birds and chameleons. Presumably this approach has been successful, since in 2004 the government of Madagascar announced an official target to increase the area in national parks from $17,000 \mathrm{~km}^{2}$ to $60,000 \mathrm{~km}^{2}$ to counter current deforestation at well over $2000 \mathrm{~km}^{2}$ annually (Pawliczek \& Mehta, 2008; Repoblikan'i Madagasikara, 2009). This would represent an increase to around $10 \%$ of the country's total area.

At this broadest level, the political involvement of the commercial ecotourism sector is largely passive. The sector generates revenue, brings in foreign exchange and provides employment, but there are few reported examples where individual operators have taken part in active lobbying efforts. As outlined below, some commercial operators do provide support for environmental NGOs which are actively involved in lobbying. At a more local scale, there are examples where individual ecotour operators, and occasionally also industry associations, have lobbied directly for government actions or policy changes in favour of conservation. Such activity may be difficult to identify as it may not always be public, and even if it is, it may be short-lived and unrecorded.

This topic does not seem to have attracted significant research attention, but a few cases have been reported. Conservation Corporation Africa, now renamed \&Beyond, (www.andbeyondAfrica.com) lobbied successfully for the creation of the Greater St Lucia conservation area in South Africa (Carlisle, 2007; Varty \& Buchanan, 1999). In Brazil, Cristalino Jungle Lodge (2009) claims to have lobbied successfully to create Cristalino State Park. The US-based Earth Science Expeditions (ESE) lobbied for creation of the Great Rivers National Park in Yunnan, China, which was ultimately achieved when The Nature Conservancy joined the lobbying effort (Buckley, 2006). In Chile, Expediciones Chile lobbied against hydroelectric dams on the Rio Futaleufu (Buckley, 2006), successfully to date; and in Tibet, ESE offshoot Last Descents has lobbied for river conservation corridors (Bowerman, 2008). Australia-based operator World Expeditions lobbied to close a road through a national park in Tasmania (Buckley, 2003a); and Costa Rica Expeditions lobbied against a road through the Tortuguero Conservation Area (Rome, 2007). In Canada, Aurum Lodge issued a public statement opposing mining in a public forestry area of high conservation value (Buckley, 2003a).

More often put forward, but even less well evaluated, is the possibility that individual clients of commercial ecotourism operations could become active and effective political lobbyists for conservation as a result of their ecotourism experiences. This suggestion is often made by tourism corporations or industry associations arguing for access or development rights in public protected areas. There seem to have been few attempts to test whether such an effect actually occurs (Beaumont, 2001). This mechanism would 
not, in any event, yield a net conservation gain unless three criteria were all met simultaneously: (a) there was a net marginal increase in political activism, due specifically to the ecotourism experience; (b) such activism was effective in improving actual conservation outcomes; and (c) such gains outweighed the aggregate environmental impacts of all clients purchasing the products concerned. This mechanism thus remains potentially significant, but untested.

\section{Contributions to NGOs}

Rather than engaging directly in political lobbying or activism for conservation, commercial ecotourism operators or their clients may provide support to environmental NGOs which do so. Such support may be either in cash or in-kind, and may be provided either to local, national or global NGOs. There are examples of each. Companies such as Costa Rica Expeditions have reportedly made donations to the Costa Rica National Parks Foundation and the Costa Rica Conservation Association (Rome, 2007). According to Brightsmith et al. (2008), ecotour operator Rainforest Expeditions has contributed about US\$278,000 worth of support to the Tambopata Macaw Project in Peru, at a cost to the company of about $\$ 98,000$; but the company has also received about $\$ 300,000$ in gross income associated with the project. In Namibia, the Desert Rhino tented camp operated by Wilderness Safaris provides staff salaries and equipment for local operations by the Save the Rhino Trust (Buckley, 2006). The Trust's staff act as rhino trackers for Wilderness Safaris guests, and funds are also raised by Save the Rhino Trust International. In Kenya, Robin Hurt Safaris has solicited significant client donations to the Cullman and Hurt Community Wildlife Project (Clarke, 2001).

Though small in comparison to public conservation funding worldwide, many of these contributions may nonetheless be quite substantial for the enterprises involved, and quite significant for conservation at a local scale. Depending on the site and species involved, some of them may also be significant at a global scale. For example, in-kind support for NGOs from two yacht-based bear-watching tour operators at Khutzeymateen in northern British Columbia, Canada, led directly to declaration of the area as a public conservation reserve. This made a significant contribution to conservation of an entire river catchment and its associated forest and grizzly bear population, since the surrounding areas were all logged and this would also have occurred for Khutzeymateen if the reserve had not been declared.

There are also cases where NGOs themselves conduct or establish commercial ecotourism operations, most commonly as a tool in community development and in raising awareness to improve local support for conservation. Examples in Australia include Earth Sanctuaries (Buckley, 2003a) and the Mareeba Wetland Foundation (Nevard, 2005). In Indonesia, Sproule and Suhandi (1998) described tours operated by local NGO Bina Swadaya. In the Seychelles, an NGO now known as Nature Seychelles conducts a commercial tourism operation on Cousin Island (Shah, 2002). In Brazil, Conservation International (2009) is involved in commercial operations at Fazenda Rio Negro and the Una Ecopark. There are also cases where local communities have themselves formed NGO-style organisations which run commercial ecotourism ventures with positive outcomes for conservation. Examples include the Cofan community at Zabalo in Ecuador (Borman, 2008). Most of these examples are rather small-scale, but they may still be significant locally. Some threatened plant and animal species are restricted to very small remnant areas, so even small-scale effects can potentially be 
significant. The actual conservation outcomes of these NGO ecotourism ventures have rarely been evaluated. In some cases all that is recorded are self-reported community attitudes.

A number of the examples of ecotourism described to date seem to have been initiated by environmental NGOs in attempts to reduce local community impacts on conservation areas by providing alternative income sources. Some of these have been analysed quite extensively, such as the Annapurna Conservation Area Project (Gurung, 2008), and the 'baboon' sanctuary in Belize, initiated by the Belize Audubon Society (Alexander, 2000). A number are initiatives by Conservation International (2009) which established village-based ecotourism projects at Chalalan in Bolivia, Kakum in Ghana, and Wekso in Panama. The island conservation group Seacology (2008) has apparently also started several such projects in Fiji and Samoa. The Eselenkei Project in Kenya, established by Porini Ecotourism with assistance from the International Fund for Animal Welfare, was described by Grieves-Cook (2002) and still seems to be operational. Many other examples listed by Buckley (2003a), however, no longer seem to be referred to in current literature or websites.

Vasconcellas-Pepes and Stronza (2008) cite a number of previous evaluations of community ecotourism enterprises initiated by NGOs. Few if any seem to have yielded positive outcomes for conservation. An evaluation of three projects in Belize by Lindberg et al. (1996) yielded equivocal outcomes. Belsky's (1999) re-evaluation of one of these, the Gales Point manatee project, was unequivocally damning, and the same applies for Barkin's (2003) analysis of the Monarch Butterfly programs in Mexico. Vasconcelles-Pêgas and Stronza (2008) cite the articles by Salafsky and Wollenberg (2000) and Salafsky et al. (2001) as providing examples where NGO-based ecotourism did prove an effective tool in conservation, but in fact neither of those articles describes actual conservation outcomes - that was not their focus. Vasconcelles-Pêgas and Stronza (2008) also indicate negative conservation outcomes at a community turtle ecotourism project at Ostional in Costa Rica, citing Campbell (2007); at Cuyabeno in Ecuador, citing Wunder (2000); and even the much-lauded Posada Amazonas, in Peru, where they note (p. 168) "continued hunting in the community's 3000 ha reserve", and that "tourism profits are not enough to sustain conservation, especially in the absence of trust that others will also cooperate to protect resources”.

\section{Contributions to Parks Agencies}

From most of the mainstream literature on parks and recreation management, one would conclude that neither the concept of ecotourism, nor the existence of ecotour operators, has made any noticeable difference to the management of protected areas and their visitors (Lockwood et al., 2006). Protected area management agencies in many countries do, however, charge a wide range of entrance, camping and activity fees both for individual visitors and for commercial tour operators and their clients. The structures, effects and acceptance of such fees have been reported for a number of nations, including Australia (Buckley, 2003a), Canada (Eagles, 2002), Costa Rica (Chase et al., 1998; Lindberg \& Aylward, 1999), Indonesia (Walpole et al., 2001), and the USA (Ostergren et al., 2005). 
Some parks set different fees for overseas and domestic visitors. Some set different fees for commercial tour clients, either higher or lower than for independent visitors; some charge the same rates. Some parks agencies are permitted to keep these fees, whereas others must pay them into central government treasuries. Some earmark fees for local use, others redistribute them. Some use them only to offset costs of visitor facilities, whereas others do not make such a distinction. In some cases, the net fees collected do not cover even the costs of visitor facilities, so there is no net contribution to conservation management. In other cases, however, visitor fees for heavily-visited parks may yield sufficient revenue to run the parks concerned and a surplus to help fund less often visited parks elsewhere. At a global scale, therefore, compulsory parks fees charged to commercial ecotour operators may sometimes represent a net positive contribution to conservation, and sometimes not. It depends on a wide range of economic, political and market factors. The key issue, perhaps, is that irrespective of the net outcome, these fees are compulsory charges set and levied by government agencies, not voluntary contributions by commercial tour operators.

There are indeed examples where commercial ecotour operators do make voluntary contributions to public protected area management agencies, but these are more often made in kind so as to ensure that they are used in the particular park and for the specific purpose which the tour operator intends. Direct cash contributions by commercial ecotourism operators to public protected area management agencies were reported by Buckley (2003b), though with no direct audits, for two companies in Costa Rica. More recently Kohl $(2007,2008)$ suggests that a new ecotourism operator in Guatemala will contribute cash to Tikal National Park. One particularly significant contribution was the relocation of rhino to Moremi National Park in Botswana, carried out by Wilderness Safaris (2009). Not surprisingly, such contributions are more commonplace in developing nations with poorly-funded parks agencies. In some cases, tour operators provide equipment such as 4WD vehicles or two-way radios. In some they pay parks rangers either directly, or via a conservation NGO operation in the park concerned. In some cases they contribute to conservation management or monitoring operations, e.g. by assisting in anti-poaching patrols, by funding reward schemes for surrender of snares, by transporting parks staff on patrols to remote areas, or by carrying out routine monitoring operations. Some of these contributions are rather small and perhaps intended principally for promotional value, but some may be highly significant.

\section{Community Conservation}

In some countries, large areas of land are owned under various forms of communal title. Many of these areas have significant value both for tourism and conservation as well as for local communities. The ways in which the owners of community titles are defined, and the precise bundle of legal rights conferred by the title, differ greatly between countries and jurisdictions. In general, however, all presume a broad right for residents on the land concerned to engage in primary production activities. Such activities range from subsistence pastoralism by nomadic tribes, to industrial logging by multinational corporations operating under licence from local community landholders. In most cases, these activities reduce the value of the land concerned for tourism and conservation alike. If commercial ecotourism operations can change land use practices towards conservation management, therefore, this represents a positive environmental outcome. 
Examples of commercial ecotourism operations on community lands are now widespread (Figgis \& Bushell, 2007). Reviews of the numerous cases in Botswana, Namibia, South Africa and Tanzania were provided recently by Carlisle (2007), Loon et al. (2007), Massyn (2008), Barnes (2008), Spenceley (2008b) and Nelson (2008) respectively. Many of the lodges run by the two largest ecotourism operations in sub-Saharan Africa, namely \&Beyond in Tanzania and Wilderness Safaris in Botswana and Namibia, are on community lands (Buckley, 2009; Carlisle, 2007). These projects have contributed to conservation connectivity corridors, wildlife reintroductions, habitat protection, and reduced livestock grazing and wildlife hunting and poaching (Buckley, 2008a, b). In East Africa, Porini Ecotourism in the Maasai-owned Eselenkei area extends Amboseli National Park in Kenya (Grieves-Cook, 2002), and Oliver's Camp provides a $20 \mathrm{~km}^{2}$ reserve in Maasai lands in Tanzania. Examples reported from Australia include Desert Tracks on Pitjantjatjara land (Buckley, 2003a), Terra Safaris on Manyallaluk lands (Schmiechen, 2002) and the Umorrduk Tours Company on Gummulkbun lands (Zeppel, 1998). In Asia, examples include the Sukau Rainforest Lodge (2009) on Iban lands in Borneo; and the Baghmara Community Forest which extends Chitwan National Park in southern Nepal (Rijal, 1997). In Central America, examples include the Cofan community at Zabalo in Ecuador (Borman, 2008); the RICANCIE group on Napo Runa lands (The Nature Conservancy, 2009); the Wekso Ecolodge on Teribe lands in Panama, extending Amistad National Park (Conservation International, 2009), and the Tambopata Reserve run by Rainforest Expeditions on Ese'eja land in Peru, extending Bahuaja-Sonene National Park (Gordillo Jordan et al., 2008; Nycander, 2002). Buckley (2003a) listed some 80 previously published examples of ecotourism operations involving local communities, but only a few are relevant here, for several reasons: (a) only some involved land held under community title (b) conservation outcomes were not considered specifically; and (c) many of these examples were reports published over a decade ago, so land tenure or community aspirations may have changed, ecotourism projects may no longer be operational, and conservation outcomes may be different than anticipated.

The contributions of ecotourism to conservation on community-owned lands are often difficult to evaluate, either in developing nations and in areas owned or managed by Indigenous peoples in developed nations. Local communities typically depend on these areas for their livelihoods, and in many cases live inside them. They may see ecotourism, generally including cultural components, as a significant source of cash income, but they may also wish to continue traditional subsistence activities, or modern hunting, which may conflict with ecotourism opportunities. In addition, in promoting growth in tourism they may generate community changes associated with cultural commodification, economic inequities, and so on which may or may not prove welcome. From the perspectives of commercial ecotour operators and their clients, issues such as these may generate some difficult paradoxes. Most of these are essentially social, and hence outside the scope of the current evaluation. They may, however, have environmental implications, for example as regards conservation of endangered plant or animal species. Examples include: Himalayan thar in Nepal (Gurung, 2008); narwhal in the Canadian Arctic (Buckley, 2005); a wide range of species in sub-Saharan Africa (Spenceley, 2008b); and lemurs in Madagascar (Pawliczek \& Mehta, 2008).

\section{Private Conservation Reserves}


The clearest positive contribution to conservation by commercial ecotourism operators, the operation of private conservation reserves, is even more direct than those outlined above. A number of operators have established such reserves, rehabilitated and re-stocked them as required, and now fund their running costs by operating commercial tourism ventures on site. The most common tourism model involves up-market game or wildlife-watching lodges which can generate sufficient revenue to run the reserve as well as the lodge itself. Private reserves in some countries can also trade individual animals of high tourism and conservation value with other private reserves and public conservation agencies. This can earn additional net revenue once the reserve is fully re-stocked and breeding programmes are well established.

Such reserves are now quite numerous, especially, but by no means exclusively, in sub-Saharan Africa (Spenceley, 2008a). The largest collection is that of \&Beyond (2009), particularly in South Africa. Other major groups of private reserves in South Africa include those in the $650 \mathrm{~km}^{2}$ Sabi Sands and Madikwe areas (Buckley, 2006; Carlisle, 2007; Loon et al., 2007; Relly, 2008; Spenceley, 2008b). Wilderness Safaris also operates a number of private reserves, including North Island in the Seychelles (Buckley, 2008a). Taj Safaris, a joint venture between Taj Hotels and \&Beyond in India, operates tiger-watching lodges on private lands adjacent to national parks. There are also numerous private reserves funded by ecotourism in South and Central America, such as the $60 \mathrm{~km}^{2}$ Cristalino reserve in Brazil, the $100 \mathrm{~km}^{2}$ Monteverde Cloud Forest in Costa Rica (Weaver, 1998) and the $5 \mathrm{~km}^{2}$ Rara Avis property bordering Braulio Carillo National Park in Costa Rica (Rome, 2007).

Worldwide, by far the majority of the land and water of high conservation value is publicly owned and managed (Bushell and Eagles, 2007). Voluntary private conservation efforts, however, are currently proving critical in efforts to extend conservation management into areas of high agricultural value and areas with a history of private land tenure predating public protected areas, and also to improve levels of landscape-scale connectivity between public protected areas (Buckley, 2008a, b). In some cases, private conservation efforts are carried out by individual landowners because of personal convictions or lifestyle reasons, with operational conservation management funding provided from external income or private wealth. The majority of private rural landholders, however, rely principally on agriculture to earn a living from their land; to convert to conservation management they need an economic incentive. For some landholders at least, tourism is one potential source of income.

Attempts to quantify the total worldwide achievements of ecotourism through private conservation are hampered by a highly incomplete dataset. Only a small number of case studies have been authenticated through independent audit (Buckley, 2003a; Stronza \& Durham, 2008). It is also difficult to establish a single scale on which to compare or aggregate their achievements. Possible quantitative measures include: the area of land or of a particular ecosystem, the number of individuals of a particular plant or animal species; the number of animal snares removed or poachers apprehended; or the financial value of conservation management measures. These measures are not easily combined. The same difficulty applies, however, for public protected areas. Indeed, one meaningful measure by which to evaluate the conservation achievements of private reserves funded through ecotourism, is to compare such reserves directly with the closest national park or other public conservation reserve. The well-known Sabi Sands area, for example, which is a patchwork of private game reserves contiguous with 
Kruger National Park in South Africa, has a total area of around $650 \mathrm{~km}^{2}$. This is not insignificant; but Kruger National Park itself has a total area of around $19,000 \mathrm{~km}^{2}$.

Contributions to conservation by this mechanism differ considerably between operators and reserves. In general, only those which provide habitat for successfully reproducing populations of threatened species make measurable and ecologically significant contributions. Most others act only as tourism attractions. Some ecotourism operations, however, have effectively extended publicly-owned national parks by a significant area or established large new conservation areas. Some, such as \&Beyond, have also contributed to conservation by developing capture, translocation, soft-release and breeding techniques for particular endangered species as part of their private reserve operations. In some cases, the same companies also contribute to conservation NGOs and to public parks agencies, and are involved in conservation lobbying at national scales.

\section{REDUCING NEGATIVE EFFECTS}

\section{Introduction and Scope}

Ways to reduce the negative environmental effects of ecotourism may be divided broadly into behavioural and technological mechanisms (Tables 4 and 5). Relevant publications fall into three fields. Firstly, the literature of sustainable tourism (Hall \& Lew, 1998; McCool \& Moisey, 2001; Stabler, 1997; Weaver, 2006) considers large-scale environmental technologies and corporate environmental management tools in the mainstream accommodation and transport sectors (Table 4). Some of these are equally applicable in the more specialised and small-scale ecotourism sector. Secondly, the literature of parks and recreation management, especially recreation ecology, considers techniques to measure and minimise the impacts of recreational visitors in outdoor areas. This includes commercial ecotourism operations and their clients (Buckley, 2004a; Bushell \& Eagles, 2007; Eagles \& McCool, 2002; Hammitt \& Cole, 1998; Liddle, 1997; Manning, 1999; Pigram \& Jenkins, 2006). The main emphasis is on behavioural management tools (Table 5). Thirdly, there is a small and specialised literature on environmental technologies and behaviour management tools developed specifically for, and by, commercial ecotourism operators and their clients. This overlaps considerably with the other two fields, and so cannot easily be examined in isolation. In each of those three fields, government agencies play a significant role through the adoption of new legislation, regulations and standards, codes of practice (Fennell \& Malloy, 2007), and certification schemes (Black \& Crabtree, 2007). There is also a related literature on ecotourism policy and planning (Diamantis, 2004; Fennell \& Dowling, 2003; Lück \& Kirstges, 2003) which provides additional context.

The key for the current analysis is to distinguish the contributions of the commercial ecotourism sector specifically. Tables 4 and 5 therefore indicate: the overall environmental significance of each mechanism for tourism worldwide; how broadly each mechanism has been adopted within the ecotourism sector specifically; and, in consequence, how much that adoption has achieved in improving environmental management performance in tourism at a global scale. Tables 4 and 5 also indicate how much the commercial ecotourism sector contributed to the initial development of each of the mechanisms listed, and how much it has contributed through the deliberate selection of environmentally improved technologies or behavioural tools, in preference 
to other options. For example, many ecolodges worldwide have chosen energy-efficient designs and installed low-impact sewage and wastewater treatment systems (Buckley, 2003a; Hawkins et al., 1995; Mehta, 2007). Similarly, many commercial ecotour operators have chosen low-impact activities and practices, established or adopted minimal-impact codes of practice, and employed guides skilled in environmental interpretation (Weaver, 2008).

\section{Technological Mechanisms}

The main types of technological mechanisms to reduce the negative environmental effects of ecotourism are listed in Table 4. Most tourists, including ecotourists, use motorised means of travel. Noise, atmospheric emissions and in some cases aquatic emissions from engines are major sources of pollution worldwide, highly significant for global environmental quality, and have attracted large-scale investment and policy attention in most developed nations. Ecotourism operators can adopt lower-impact engine technologies, but are not generally involved in developing them. For example, they may use four-stroke instead of two-stroke motors, or electric or hybrid motors for staff and client transport. Rather few actually do so, however, and generally only when required by local regulations: e.g. for access to waterways where boats are only permitted to use electric motors (Buckley, 2006).

The design, construction and operation of accommodation has been a key feature of the commercial ecotourism sector (Mehta, 2007). This includes: the adaptation of vernacular buildings and adoption of vernacular architectural styles; incorporation of local and recycled materials; energy and water supply systems and efficient use; recycling especially of catering items and other small consumables; and low-impact sewage and wastewater treatment technologies. Whilst aspects such as energy and water efficiency are of major significance at global scale, the aggregate contribution of the ecotourism sector itself is small, unless ecotourism operations provide a demonstration effect or technology test bed which leads to so-called mainstreaming of better water and energy efficiencies across the entire tourism industry. This leads us into the controversial issue of scale, considered further below (Table 7). It also leads to the semantic distinction between ecotourism and sustainable tourism. Low-impact technologies do indeed seem to have been adopted earlier, and to be more commonplace currently, in ecotourism operations than the tourism industry as a whole. There does not seem to be any definitive evidence, however, to determine whether early adoption of such technologies by ecotourism operators created regulatory and market pressures to improve the sustainability of the mainstream tourism industry; or whether such pressures developed independently as a manifestation of broader community environmental concerns (Black \& Crabtree, 2007).

\section{Behavioural Mechanisms}

The majority of mechanisms listed in Table 5 were developed by protected area management agencies and in some cases by NGOs. Arguably, most of the commercial ecotourism operators which have adopted these measures have done so for commercial reasons, either to gain access and operating permits in protected areas, or to contribute to customer satisfaction and hence to repeat business and referrals. For this analysis, however, the key consideration is outcomes rather than motivations. For some mechanisms, the outcomes are relatively clear. If high-impact activities are banned in a 
particular area, then impacts in that area are reduced accordingly. The activity and its impacts may well shift elsewhere, but if the new area is of lower value for conservation, the ban will still reduce net negative environmental effects.

For many behavioural mechanisms, however, outcomes are unclear or largely untested. Codes of practice are widespread (Buckley, 2002a; Fennell \& Malloy, 2007; Garrod \& Fennell, 2004) but evaluations to date indicate that they are largely ignored (Mason, 2007; Scarpaci \& Dayanthi, 2003; Waayers et al., 2006; Wiley et al., 2008). Minimal-impact educational messages are commonplace in park and wilderness management (Hendee \& Dawson, 2002; Lockwood et al., 2006) and in many commercial ecotours. Good guides can certainly contribute to client satisfaction (Beedie, 2003), but as noted by Kohl (2007, p. 342) there is little evidence that this contributes measurably to conservation. Numerous studies have examined how interpretation may change tourists' stated attitudes or intentions (Littlefair, 2004; Marion \& Reid, 2007). Very few, however, have evaluated the effects of environmental interpretation on actual behaviour or impacts. Roggenbuck and Berrier (1982), Oliver et al. (1985), Widner and Roggenbuck (2000) and Jacobi (2003) tested the effectiveness of parks interpretation programmes in changing the behaviour of independent park visitors. The effectiveness of interpretation by guides in reducing client impacts on commercial ecotours has been tested for divers in a coral reef ecosystem (Medio et al., 1997), and hikers in subtropical rainforest (Buckley \& Littlefair, 2007; Littlefair, 2004; Littlefair \& Buckley, 2008).

Selective marketing for environmentally concerned clients has been reported for at least one tour operator by Buckley (2006, p. 296), but with no evaluation of outcomes. Evidence for lifestyle changes or political lobbying following an educational ecotourism experience is even more limited. Most of the people who buy commercial ecotours do so as holiday makers, not activists (Bauer, 1997; Beaumont, 2001). They may well have interests in conserving nature as well as experiencing it, but there does not seem to be any controlled longitudinal study to test whether clients of commercial ecotours change their post-trip lifestyles or political activities so as to reduce environmental impacts or enhance conservation. Even if they did, there would be no net gain for the natural environment unless the outcomes of any such changes by the particular clients concerned outweighed the impacts of all the clients during the tour itself. Overall, therefore, the indications of achievements listed in Table 5 must be considered speculative, or at best approximate.

\section{GENERATING NEGATIVE EFFECTS}

\section{Introduction and On-Site Impacts}

Mechanisms by which ecotourism can generate negative impacts on the natural environment are listed in Table 6. Local on-site impacts of outdoor recreation and tourism, including commercial ecotourism, form part of the domain of recreation ecology and have attracted significant research attention (Buckley, 2004a; Liddle, 1997; Raschi \& Trampetti, 2008). One of the key aspects of ecotourism, as outlined earlier, is its attempt to reduce these impacts; but even with best practices in both technology and behaviour, ecotourists do still produce impacts on the natural environment. This is a very extensive field and no attempt is made to summarise it here. Rather, this evaluation focuses on other, more contested mechanisms. 


\section{Longhaul Travel and Climate Change}

Various proponents of ecotourism, particularly of projects involving local communities in developing nations, have argued that it brings money from rich urbanised northern societies to poor rural southern communities in a way which can, in some circumstances at least, make an effective and efficient contribution to conservation (Buckley, 2003a; Harrison, 2001; Spenceley, 2008a; Stronza and Durham, 2008). In the process, however, the tourists fly from one continent to another, and back after a short holiday; and this contributes to air pollution, noise and global warming. To evaluate the overall net effects of ecotourism on the natural environment, therefore, the environmental consequences of this longhaul travel must be considered, in addition to the more localised mechanisms which may produce positive or negative effects at the destination (Gössling et al., 2009). For any given form of transport, it is relatively straightforward to calculate carbon dioxide emissions per passenger for a given distance travelled, and thus to calculate the carbon footprint of a specified tour itinerary (Becken \& Simmons, 2002; Broderick, 2009; Byrnes \& Warnken, 2006; Ceron \& Dubois, 2009; Peeters et al., 2009). Commercial ecotourism operators, however, generally treat information on their clients' countries of origin as commercially confidential, and there are consequently very few examples where the carbon footprint of longhaul travel to an ecotourism destination has been calculated (Folke et al., 2006). To compare the conservation benefits of any particular ecotourism operation with its carbon costs would be far from straightforward.

\section{Trojan Horse Effects}

A number of authors, including Pleumarom (1993) and Wheeller (1997) have suggested that small-scale low-impact ecotourism may act as a so-called Trojan Horse, or the "thin end of the wedge", for high-impact and larger-scale tourism development. In the parks and recreation management literature the analogous term is recreational succession, where small-scale low-impact recreational activities are gradually replaced by increasingly large-scale and high-impact activities with associated infrastructure. In the tourism development literature the analogous term is disneyfication, where even the most natural attractions become increasingly hardened and artificial as they attract more visitors and can ultimately evolve into "theme parks". Such effects do indeed seem to be widespread and powerful in practice. If they wish to counter recreational succession, for example, parks agencies are forced to use stringent regulatory measures, e.g. regarding numbers, timing and activities, which have proved politically difficult to introduce except in a few exceptional circumstances. As long as commercial ecotourism operations are small-scale relative to independent visitors, it seems unlikely that they contribute more than pro rata to this effect. According to Buckley (2003a), in the absence of a strong legal conservation framework, tourism development in wilderness or pristine natural areas does indeed progress rapidly from small-scale low-impact ecotourism to larger-scale and higher-impact forms of tourism development, such as motorised adventure and fixed-site accommodation and activities. There does not seem to be any systematic research, however, on how widespread or severe such effects may be.

\section{Argument for Inappropriate Development Consent}


It has been suggested that tourism developers may sometimes use the terminology of ecotourism to gain development consent in areas where tourism development would not otherwise be permitted, even though the development then actually constructed does not satisfy all the criteria for ecotourism. This is possible since ecotourism, or at least its translation into development planning law, remains rather vaguely defined. A wide range of approaches are used by property developers to gain consent for new development proposals. Residential developments may be put forward as tourism or even environmental education proposals; large-scale developments may be put forward in small sections to bypass high-level regulatory review, and so on. Ecotourism is simply one more measure of this type. This mechanism may be of considerable environmental significance, however, if it leads to large-scale development in protected areas and other areas of high conservation value.

To test this mechanism in any individual case requires detailed local knowledge and analysis of the development and the planning process, to determine firstly whether the development would have been approved in any case, irrespective of an ecotourism label; and secondly, to what extent the development as actually built may or may not comply with the principles of ecotourism. To evaluate this potential mechanism in any broad-scale and systematic way would therefore be a very large and difficult task, which does not yet seem to have been attempted.

\section{Inequitable Partnerships}

It has been suggested (Buckley, 2004b) that, at least in some countries, the tourism industry has lobbied for partnerships between the tourism industry and protected area management agencies as a political mechanism to gain preferential access, operating permits or development rights; and that the outcomes may have net negative environmental effects. Both industry associations and individual enterprises are involved, in both the ecotourism and the mainstream tourism sectors. A recent review of contractual partnerships between the parks agency in South Africa, SAN Parks, and commercial tourism and hospitality operators (Varghese, 2008) found that they had not served either tourists or conservation well. There does not seem to have been any large-scale systematic evaluation of this mechanism internationally.

\section{Ecotourism Lite}

Authors such as Honey (1999), McLaren (1998) and Rome (2007) have argued strongly that the positive potential of ecotourism is severely debased, and perhaps completely outweighed, by the negative effects of so-called ecotourism lite or fake ecotourism. These terms refer to tourism developments and enterprises which market themselves as ecotourism, but do not in fact follow its principles or practices. This issue is also referred to, using various terminologies, in texts such as those of Fennell (1999) and Mowforth and Munt (2003). It seems clear that since there are in general no legal restrictions on use of the term ecotourism, it has indeed been adopted widely to advertise enterprises with no relevant credentials. Whether this use, or abuse, of the term ecotourism produces net negative effects on the natural environment, or whether these impacts would have occurred irrespective of the marketing terminology, is perhaps less clear. The most detailed analysis remains that of Honey (1999), who provided analyses from Ecuador, Costa Rica, Cuba, Tanzania, Kenya and South Africa. More recent reports (Buckley, 2006, pp. 353-357; Spenceley, 2008a; Stronza and 
Durham, 2008) suggest that in some of these countries at least, there are currently ecotourism enterprises which do indeed deserve that title. These, however, make up only a small proportion of the total tourism operations in those countries; it seems likely that much of Honey's analysis remains relevant today. The key aspect of her analysis was that she considered ecotourism within the broader historical, political and economic context of the countries concerned, so as to evaluate overall outcomes. This was, as she noted, "a lengthy and complex research and writing project". It remains to be seen whether anyone will be able to repeat and extend it. These are analyses of individual projects, such as Belsky (1999) of a project in Belize, but nothing else which combines both the scale and depth of Honey's analysis.

\section{Undeserved Awards and Certificates}

In an attempt to counter the problems of ecotourism lite, a number of early ecotourism practitioners proposed eco-certification schemes, intended to distinguish enterprises which did deserve the ecotourism title (Black \& Crabtree, 2007; Font \& Buckley, 2001; Honey, 2002). This was a well-intentioned approach, which had arguably achieved significant success in other industry sectors. Indeed, one of the principal proponents of this approach has been the Rainforest Alliance, which had previously achieved some success in the eco-certification of timber products (Font et al., 2003). The Rainforest Alliance has also campaigned doggedly for the establishment of an international accreditation body for tourism eco-certification schemes, analogous to the equivalent body in the timber industry, which played a pivotal role in building public trust of timber eco-certification programmes.

Some form of independent accreditation council is needed because of a proliferation of privately run tourism eco-certification programmes which themselves seem to be little more than marketing measures. There seems to have been a series of moves and counter-moves between NGOs and intergovernmental environmental agencies on the one hand, and tourism industry associations on the other, as follows:

1. NGOs proposed ecotourism as an approach to improve the environmental performance of the tourism sector.

2. Commercial tourism enterprises and industry associations co-opted this term as a marketing ploy, giving rise to ecotourism lite.

3. NGOs proposed certification programmes to identify operators which complied with their original intentions for ecotourism.

4. The industry co-opted this approach as a further marketing ploy, which we could call eco-certification lite.

5. NGOs proposed an international body to accredit tourism eco-certification schemes which comply with their original intentions for ecotourism.

6. The industry has in many cases attempted to block such an international accreditation body or render it ineffective.

According to Honey (2002) and Font et al. (2003), an international accreditation body was first proposed, under a sustainable-tourism rather ecotourism title, during the 2002 International Year of Ecotourism. According to Buckley (2002b) such a body might in fact have been established at the 2002 World Ecotourism Summit, but proposals by the Rainforest Alliance were derailed by a representative of the World Travel and Tourism Council. The most recent development (Rainforest Alliance, 2009) is the establishment of a set of sustainable tourism certification criteria, through a process which included 
mainstream tourism industry representation. This is not, however, by any means the same as an international accreditation body which has the power to evaluate and if need be, remove accreditation for individual tourism eco-certification programmes. In addition, the current emphasis is on the much vaguer concept of sustainable tourism, which lacks many of the key criteria for ecotourism.

The original argument put forward for ecotourism enterprises to join certification schemes was that ecotourists would patronise companies which were certified in preference to those which were not. There does not seem to be any evidence, however, that tourists actually adopt any such preferential purchasing strategy or that they are even aware of eco-certification programmes (Mason, 2007). It has been suggested that tourism operators seek certification in order to gain preferential treatment from regulatory authorities, such as longer operating licences in national parks (Buckley, 2009). In practice, however, it appears that parks agencies either recognise a range of business certification as well as environmental certification programmes (Ingram, 2007), or establish their own programmes (GBRMPA, 2008). In New Zealand, Rowe and Higham (2007) noted that the only tourism operators which had adopted ecocertification schemes were those which in any event required permits from the national parks agency, the New Zealand Department of Conservation.

Whilst almost any ecotourism operator can join a certification programme, there has been a perception that competitive environmental awards are available only to a small proportion of operators, and that potential clients may therefore pay more attention to awards than to certificates. Most recently, however, it has been suggested (Buckley, 2009) that even the most prestigious international environmental awards suffer from the deficiency that someone has to win them: that is, the judges have to select a winner from the shortlist in each category, even if none of the applicants necessarily merit the award concerned.

Both ineffective eco-certification programmes, and undeserved environmental awards in tourism, may thus promote the perspective that the recipients have achieved higher environmental performance than the rest of the tourism industry, even if this is not in fact the case. Even if so, however, it is not clear whether this mechanism actually generates a net negative environmental outcome, or merely represents misleading advertising.

\section{CONTROVERSIES AND CONTESTED ISSUES}

Despite two decades of debate over definitions and aims of ecotourism, some aspects remain contested, and some of these affect the evaluation of ecotourism's environmental effects. Such issues are listed in Table 7. Three of these, namely partnerships, ecocertification and long haul travel, can and sometimes do generate negative environmental effects, as summarised in the previous section. They are included in Table 7 to acknowledge that they remain active areas of debate. Two more issues, namely local empowerment and poverty alleviation, are generally considered under the social rather than environmental goals; but as outlined in the section on generating positive effects, both these aspects of ecotourism can produce effects on the natural environment. 
The sixth controversial issue is that of scale and mainstreaming. As summarised in Table 7, some ecotourism analysts take the view that small scale is an essential defining criterion of ecotourism, whereas others argue that to achieve anything of global significance, ecotourism must either expand in scale itself, or modify the way in which the mainstream tourism industry operates. The International Ecotourism Society, for example, argues for "a world in which all tourism is ecotourism" (Ezaki, 2009). If this large-scale view is taken, then any evaluation of ecotourism should consider how successful the ecotourism sector has been in expanding its scale. If the small-scale view is accepted, however, then such an evaluation is not only unnecessary, but inappropriate. This issue is therefore not addressed here. It is worth noting, however, that some of the ecotourism operators which have received the highest accolades for their conservation achievements, such as \&Beyond and Wilderness Safaris, have pursued quite aggressive expansion strategies over the past decade, apparently on the grounds that if they can achieve positive financial, social and environmental outcomes at one site, then it is worth applying the same model to as many other sites as possible. Wilderness Safaris has restricted its expansion to sub-Saharan Africa, but \&Beyond, in partnership with a locally-based hotel company, has also expanded into India. Retail tour packagers such as Natural Habitat Adventures and World Expeditions, which have also achieved widespread recognition for socially and environmentally responsible operations, have also continued to expand the scale of their tour portfolios.

This is not to denigrate the achievements of small-scale community-style ecotourism ventures, where even a small additional income can make a major difference to community wellbeing and community use of natural resources. It simply indicates that within the ecotourism sector as a whole, some well-respected enterprises are now quite large in scale. As noted by Cater and Cater (2007) for example, if dive tourism is accepted as a form of ecotourism - and it certainly does seem to comply with the defining criteria - then it is worth noting that there are over 25 million certified divers worldwide. Cater and Cater (2007, p. 13) also quote Buckley (2003a, p. 241): "there is nothing scale-dependent about a nature-based product, minimal-impact management, environmental education or contributions to conservation" and similar sentiments expressed by Weaver (2001). Concern over the various ways in which ecotourism can be used as an excuse for large-scale, high-impact, industrial-style tourism development is certainly legitimate, as outlined earlier. This in itself, however, does not make large-scale ecotourism impossible, or even undesirable. Perhaps the key issue is not the absolute size of an ecotourism operation or development, but scale relative to the natural environment and nearby communities: i.e., a question of social and environmental. carrying capacities, limits to acceptable change and related issues.

\section{CONCLUSIONS}

\section{Framework}

The aims of this contribution were firstly, to construct a framework to evaluate the environmental effects of ecotourism; secondly, to evaluate these effects as far as possible using currently available data; and thirdly, to identify future research required for a more comprehensive evaluation.

As noted at the outset, there are many possible frameworks for such an evaluation. The framework adopted here focuses principally on the net outcomes for the natural 
environment, since that is the overall aim of this evaluation. As units of evaluation, it uses the many different potential mechanisms by which ecotourism could affect the natural environment. Again, as noted earlier, the degree to which such mechanisms are subdivided, the ways in which they are distinguished, and the categories into which they are clumped, themselves represent choices made as part of this analysis. To some degree, these choices probably reflect the historical evolution of relevant research fields and associated academic literature, though this analysis has endeavoured to draw data from all relevant sources, irrespective of how the publications concerned were originally labelled. The framework adopted is thus a classification of convenience, not a philosophical statement about ecotourism.

This framework can be presented graphically as in Figure 1. The fourth corner of the square is not needed since it would represent mechanisms by which ecotourism reduced pre-existing positive environmental effects of mainstream tourism. By definition, any such effect would necessarily represent misuse of the ecotourism name. It would also be indistinguishable in practice from mechanisms by which ecotourism can generate negative environmental effects. Figure 1 also includes zero-effect cells, which are indistinguishable from each other, and represent cases where the effects of ecotourism on the natural environment are essentially indistinguishable from those of mainstream tourism, even if the products, enterprises or activities concerned are labelled as ecotourism.

Using the data summarised in Tables 3 to 6 , Figure 1 can be expanded to indicate relative rankings of different mechanisms, as in Figure 2. These rankings are necessarily rough, because different individual examples of ecotourism have different net environmental effects. The rankings in Figure 2 are approximations based on what appears to have been achieved worldwide to date, in aggregate, for the mechanisms listed.

\section{Evaluation}

It is not yet possible to determine the overall net environmental bottom line for ecotourism as a whole. There are three major barriers to such an evaluation. The first barrier is that the overall bottom line depends on what is included in the aggregate evaluation, and this still seems subject to disagreement. For example, if an independent traveller follows the principles of ecotourism, are they then an ecotourist, or is this term applied only to clients of commercial ecotourism enterprises? If the former, is the political role of independent travellers in helping to establish and maintain funding for public protected areas, considered as a positive environmental effect of ecotourism? Equally, should the impact of such visitors in public protected areas be considered as one of its negative environmental effects?

Similarly, should the use or mis-use of the ecotourism label in the various mechanisms listed in Table 6, be included in the evaluation on the grounds that if there were no ecotourism, there could be no ecotourism lite? Or should these effects be excluded from the evaluation, on the grounds that such products and enterprises are not, in fact, ecotourism? Likewise, should the possible role of ecotourism in improving the sustainability of the mainstream tourism industry be included in the evaluation, on the grounds that ecotourism led the way and developed the techniques and markets for sustainable tourism; or should it be excluded on the grounds that ecotourism is a 
specialist product subsector, and sustainable tourism represents a large-scale and independent trend towards improved environmental management across the entire tourism sector? And as a related issue, if a small tourism operation which complies with the principles of ecotourism then grows to become a large operation but with no changes other than scale, should this be included as ecotourism, or excluded on the grounds that ecotourism refers only to small-scale enterprises? None of these issues involve technical difficulties: they are essentially problems of definition.

The second barrier to calculating an aggregate environmental bottom line for the ecotourism sector, however, does indeed involve severe technical difficulties. It is essentially an accounting problem: there are no generally agreed parameters or accounting protocols to quantify and compare the various different types of environmental costs and benefits which ecotourism may generate (Buckley, 2003c). This difficulty can be addressed to some degree from a technical perspective, where there are quantifiable ecological relationships between different parameters so that equivalence factors can be calculated. Most of the various environmental parameters affected by ecotourism, however, are neither equivalent nor interconvertible. It is well beyond the state of current ecological knowledge to compare, for example, how critical each may be to the continuing function of the planetary ecosystem. To calculate a net aggregate environmental bottom line for ecotourism, therefore, we need either a balance-sheet approach where we simultaneously evaluate the net aggregate positive or negative outcome for a basket of numerous independent parameters; or an accounting protocol, where we agree on some systematic approach to set equivalence factors between different parameters, with these factors thus being determined by a human social process rather than a technical ecological investigation. This kind of approach is used implicitly, for example, in judging processes for environmental awards, which must effectively determine at least a partial ranking between a range of rather different environmental achievements.

The third major barrier to an overall evaluation is that many of the potential mechanisms considered here involve complex social and political processes, and have simply not been studied for a sufficient number of ecotourism products or enterprises to provide any general picture of their environmental significance. Many of these mechanisms are in fact very difficult to dissect or test. Even for a seemingly straightforward mechanism such as the use of minimal-impact interpretation by ecotour guides to reduce the local on-site environmental impacts of their clients, the practical difficulties in carrying out a reasonably rigorous test of actual environmental outcomes were not overcome until several decades after the measure itself was in widespread use; and even now, such tests have only been carried out in very limited circumstances. Questions such as whether ecotourism clients may actually change their post-trip lifestyles, purchasing patterns or political activities in such a way as to create a net outcome for the natural environment, remain unresolved, even though the suggestion is by no means a new one. Similar considerations apply in evaluating the various potential mechanisms for ecotourism to generate net negative impacts on the natural environment, as outlined in Table 6. In general, we have more information about mechanisms which are straightforward but very localised, such as small-scale recycling programmes or installation of energy-efficient light globes, than we do on mechanisms which are less direct but potentially much more significant at global scale, such as changes in political activism. 
Because of these barriers, an overall evaluation of the net effect of ecotourism on the natural environment can currently be couched only in relatively broad terms. There are a small number of excellent examples, where commercial ecotourism corporations have: adopted a wide range of measures to reduce negative environmental effects; taken a wide range of measures to encourage their clients to contribute to conservation; and made on-ground contributions to conservation which are of considerable local and perhaps more widespread ecological significance (Buckley, 2008a; Vasconcellos-Pêgas and Stronza, 2008). There are also a number of instances where commercial enterprises branded as ecotourism have created net negative effects on the natural environment, through a variety of mechanisms. Perhaps the vast majority of operations labelled as ecotourism, however, are little different from the rest of the tourism industry, the so-called mainstream sector. That is, the fact that they are labelled as ecotourism is largely irrelevant. In calculating an aggregate net environmental bottom line for ecotourism, these operations would appear more as noise than as data points.

\section{Research Priorities}

The barriers to evaluation, as outlined above, suggest three main priorities for research. One of these, environmental accounting techniques to compare and aggregate a range of different positive and negative effects, is a topic which transcends any particular industry sector and is thus probably beyond the scope of ecotourism research specifically.

The top priority within ecotourism research itself, and indeed equally relevant for sustainable tourism more broadly, is surely to follow through the less-studied mechanisms outlined here, to determine precisely what outcomes they produce, and to what extent those outcomes are attributable to ecotourism. Some of these mechanisms, such as technologies, fees and regulations, are already heavily studied. Some, such as codes, interpretation and marketing, have been tested on occasion but deserve further study. Some of the most significant, however, such as community and political mechanisms, post-trip lifestyle change, and the various effects listed in Tables 6 and 7, remain conjectural and controversial and merit particular attention. We need to assemble examples of each of these mechanisms and analyse their actual outcomes, using a detailed contextual approach such as that adopted by Honey (1999).

In this process we should also add the remaining research priority, which is to study how actual ecotourism products and enterprises function in the real world, as well as how ecotourism might or should operate in an ideal world. To evaluate progress or outcomes in ecotourism we need large sets of detailed real-world data: not merely extracts from previous publications as compiled by authors such as Buckley (2003a), but comprehensive sets of analyses making full use of all the social and political tools of tourism studies.

Is this, then, a counsel of despair? Not at all. Ecotourism is now a large part of the political lexicon of tourism development, protected area management and community development. The term may not always be used as tourism researchers and environmental NGOs think it should, but it has developed a life of its own, well beyond its originators. Indeed, those same originators have promoted the concept and encouraged its widespread adoption. The creature has been created, and different interests seek to harness it for their own purposes. Academic researchers may no longer 
have much control over where it goes, but they do perhaps have a continuing obligation to watch and report on what it does. The evaluation presented here may perhaps provide a first benchmark. A more comprehensive and accurate evaluation is perhaps beyond the capability of any single analyst, and will require an organised and simultaneous pooling of up-to-date field knowledge from ecotourism researchers internationally, a multi-authored compilation of data from ecotourism enterprises worldwide. 


\begin{tabular}{lll}
\hline Mechanism & Tourism terms & Associated fields \\
\hline
\end{tabular}

\section{Generating Positive Effects}

Political action

Support for NGOs

Support for parks agencies

Community reserves

Private reserves

\section{REDUCING NEgATIVE EFFECTS}
Environmental technologies
travel
accommodation
activities
Behaviour management tools
regulations
fees, incentives
codes of practice
ecomarketing
education, interpretation
post-trip lifestyle change

\section{GENERATING NEGATIVE EFFECTS}

Environmental impacts

Greenhouse emissions

Development in parks

Ecotourism lite

Undeserved awards

\section{CONTROVERSIES AND CONTESTED ISSUES}

Mainstreaming and scale

Local empowerment

Poverty alleviation

Ecolabels and awards policy

[ecotourism]

partnerships

[ecotourism]

sustainability

sustainability

sustainability

sustainability

nature-based

nature-based

sustainability

nature, adventure

marketing

guiding

leisure

[ecotourism]

offsets, mitigation

partnerships

greenwash

certification responsibility development studies

conservation

parks and recreation

development studies

conservation policy environmental audit environmental audit environmental audit environmental audit parks and recreation parks and recreation environmental economics ethics, behaviour marketing outdoor education leisure studies

recreation ecology

climate change

politics

marketing

marketing

business, marketing

politics

development studies

marketing 
Table 2 Case Studies of Commercial Ecotourism in Tourism Books 20032008

\begin{tabular}{|c|c|c|}
\hline Publication & Cases & Comments \\
\hline Spenceley, 2008a & 6 & $\begin{array}{l}\text { focus on "responsible" tourism; } 4 \text { chapters describe } \\
\text { case studies in commercial ecotourism; several } \\
\text { chapters also provide comparative reviews }\end{array}$ \\
\hline $\begin{array}{l}\text { Stronza \& Durham, } \\
2008\end{array}$ & 11 & $\begin{array}{l}\text { Americas only; } 10 \text { chapters include case studies; } \\
\text { some cases included in several chapters }\end{array}$ \\
\hline Weaver, 2008 & 5 & $\begin{array}{l}\text { textbook, includes } 5 \text { case studies drawn from other } \\
\text { publications }\end{array}$ \\
\hline Bushell \& Eagles, 2007 & 3 & includes 3 chapters with 1 case study each \\
\hline Buckley, 2006 & 9 & case studies in chapter on wildlife tourism \\
\hline Hall \& Boyd, 2005 & 1 & one chapter is a case study of a commercial ecotour \\
\hline Singh, 2004 & 3 & 1 chapter with 2 case studies, 1 with 1 \\
\hline UNEP TOIST, 2003 & 2 & $\begin{array}{l}\text { self descriptions by industry association members, } \\
\text { including } 2 \text { ecotours }\end{array}$ \\
\hline Buckley, 2003a & 170 & $\begin{array}{l}\text { very broad and inclusive selection, detail very } \\
\text { variable; only } 50 \text { cases audited by author, rest } \\
\text { rewritten from previous publications, including } 16 \\
\text { cases from } 2 \text { UNWTO compilations; many of the } \\
\text { cases may no longer be operational. }\end{array}$ \\
\hline
\end{tabular}

Note: Many other books also cite previous publications or particular case studies, but do not present them in detail or compile collections. 
Table 3 Mechanisms for Ecotourism to Generate Positive Environmental Effects

\begin{tabular}{|c|c|c|c|c|c|}
\hline \multirow[t]{2}{*}{ Mechanism } & \multirow{2}{*}{$\begin{array}{l}\text { Potential } \\
\text { environmental } \\
\text { significance }\end{array}$} & \multirow{2}{*}{$\begin{array}{l}\text { Breadth of } \\
\text { adoption in } \\
\text { ecotourism } \\
\text { sector }\end{array}$} & \multirow{2}{*}{$\begin{array}{l}\text { Achievement } \\
\text { in practice, } \\
\text { global scale }\end{array}$} & \multicolumn{2}{|c|}{$\begin{array}{l}\text { Attributable } \\
\text { to ecotourism }\end{array}$} \\
\hline & & & & develo & select \\
\hline \multicolumn{6}{|l|}{ Political } \\
\hline parks policies & $* * *$ & * & ** & - & $* *$ \\
\hline CTO lobby & $* *$ & $*$ & $*$ & $*$ & $* *$ \\
\hline clients lobby & $*$ & $*$ & $*$ & $*$ & $*$ \\
\hline \multicolumn{6}{|l|}{ Support NGOs } \\
\hline CTO cash & $* *$ & $*$ & $*$ & $* *$ & $* *$ \\
\hline CTO in-kind & $*$ & $* *$ & $*$ & $* *$ & $* *$ \\
\hline clients local & $* *$ & $*$ & $*$ & - & $* *$ \\
\hline clients global & $*$ & $* *$ & $* *$ & - & $*$ \\
\hline NGO as CTO & $* *$ & $*$ & $*$ & $* *$ & $* *$ \\
\hline \multicolumn{6}{|l|}{$\begin{array}{l}\text { Contribute to parks } \\
\text { agencies }\end{array}$} \\
\hline compulsory fees & $* *$ & $* *$ & $*$ & - & $*$ \\
\hline cash donations & $*$ & $*$ & * & * & * \\
\hline staff salaries & $* *$ & $*$ & $*$ & $*$ & $* *$ \\
\hline equipment & $* *$ & $*$ & $*$ & $*$ & $* *$ \\
\hline operations & $* *$ & $*$ & $*$ & $*$ & $*$ \\
\hline \multicolumn{6}{|l|}{ Community conservation } \\
\hline lease land & $* * *$ & $*$ & ** & $* *$ & ** \\
\hline employ locals & $* *$ & $* *$ & $*$ & $* *$ & $* *$ \\
\hline client purchases & $*$ & $* *$ & * & $* *$ & ** \\
\hline community-owned ops & $*$ & $* *$ & $*$ & $* *$ & $* *$ \\
\hline revenue-sharing & $* *$ & $*$ & $*$ & $*$ & $*$ \\
\hline Private reserves & $* * *$ & * & $* *$ & * & $* *$ \\
\hline
\end{tabular}

Key: ***, major; **, medium; * , minor; -, nil or not applicable 


\begin{tabular}{|c|c|c|c|c|c|}
\hline \multirow[t]{2}{*}{ Mechanisms } & \multirow{2}{*}{$\begin{array}{l}\text { potential } \\
\text { environmental } \\
\text { significance, } \\
\text { global tourism }\end{array}$} & \multirow{2}{*}{$\begin{array}{l}\text { breadth of } \\
\text { adoption, } \\
\text { ecotourism } \\
\text { sector }\end{array}$} & \multirow{2}{*}{$\begin{array}{l}\text { achievements } \\
\text { in practice, } \\
\text { global scale }\end{array}$} & \multicolumn{2}{|c|}{$\begin{array}{l}\text { attributable to } \\
\text { ecotourism }\end{array}$} \\
\hline & & & & devel & select \\
\hline \multicolumn{6}{|l|}{ travel } \\
\hline engine efficiency & $* * *$ & $* *$ & $*$ & - & $*$ \\
\hline emission reduction & $* * *$ & $* * *$ & $*$ & - & * \\
\hline noise reduction & $* *$ & $* *$ & $*$ & - & $*$ \\
\hline \multicolumn{6}{|l|}{ accommodation } \\
\hline design & $*$ & $* * *$ & $*$ & $* *$ & $* *$ \\
\hline materials & $*$ & $* *$ & $*$ & $*$ & $* *$ \\
\hline energy & $* * *$ & $* * *$ & $*$ & $*$ & $* *$ \\
\hline water & $* * *$ & $*$ & $*$ & $*$ & $*$ \\
\hline recycling & $* *$ & $* * *$ & $*$ & $*$ & $*$ \\
\hline sewage and wastewater & $* *$ & $* * *$ & $*$ & $*$ & $* *$ \\
\hline \multicolumn{6}{|l|}{ activity sites } \\
\hline $\begin{array}{l}\text { hardening, e.g. } \\
\text { walkways }\end{array}$ & $*$ & $* * *$ & $*$ & $*$ & $* *$ \\
\hline toilets, waste disposal & $* *$ & $* * *$ & $* *$ & $*$ & $* *$ \\
\hline $\begin{array}{c}\text { remote and infrared } \\
\text { cameras }\end{array}$ & $* *$ & $*$ & $*$ & $*$ & $* *$ \\
\hline
\end{tabular}

Key: ***, major; **, medium; * ,minor; -,nil or not applicable 


\begin{tabular}{|c|c|c|c|c|c|}
\hline \multirow[t]{2}{*}{ Mechanism } & \multirow{2}{*}{$\begin{array}{l}\text { Potential } \\
\text { environmental } \\
\text { significance }\end{array}$} & \multirow{2}{*}{$\begin{array}{l}\text { Breadth of } \\
\text { adoption in } \\
\text { ecotourism } \\
\text { sector }\end{array}$} & \multirow{2}{*}{$\begin{array}{l}\text { Achievement } \\
\text { in practice, } \\
\text { global scale }\end{array}$} & \multicolumn{2}{|c|}{$\begin{array}{l}\text { Attributable to } \\
\text { ecotourism }\end{array}$} \\
\hline & & & & devel & select \\
\hline \multicolumn{6}{|l|}{ Regulations } \\
\hline tenure & $* * *$ & - & $* *$ & - & * \\
\hline zoning & $* *$ & - & $* *$ & - & $*$ \\
\hline quotas & $* *$ & - & $*$ & * & $*$ \\
\hline equipment & $* *$ & $* *$ & $*$ & $*$ & $* *$ \\
\hline activities & $* *$ & $* *$ & $* *$ & - & $* * *$ \\
\hline practices & $* *$ & $* *$ & $*$ & * & $* * *$ \\
\hline qualifications & $*$ & $* *$ & $*$ & $*$ & $*$ \\
\hline \multicolumn{6}{|l|}{ Economic incentives } \\
\hline differential fees & * & $*$ & * & - & * \\
\hline grants and rewards & $*$ & $* *$ & $*$ & $*$ & $*$ \\
\hline \multicolumn{6}{|l|}{ Codes of practice } \\
\hline government & $*$ & $* *$ & $*$ & $*$ & $* *$ \\
\hline industry association & $*$ & $* *$ & $*$ & $*$ & $* * *$ \\
\hline tour operator & $*$ & $*$ & $*$ & $*$ & $* * *$ \\
\hline third-party & $*$ & $* *$ & $*$ & $*$ & $* *$ \\
\hline \multicolumn{6}{|l|}{ Selective marketing } \\
\hline by operators & $*$ & $*$ & $*$ & $*$ & $*$ \\
\hline by land managers & $*$ & $*$ & - & - & - \\
\hline by destinations & $*$ & $*$ & - & - & - \\
\hline \multicolumn{6}{|l|}{ On-site interpretation } \\
\hline guides & $*$ & $* * *$ & $*$ & $* *$ & $* * *$ \\
\hline signs and displays & $*$ & $* * *$ & * & $*$ & $* *$ \\
\hline brochures & $*$ & $* * *$ & $*$ & $* *$ & $* *$ \\
\hline Post-trip lifestyle & & & & & \\
\hline reduced footprint & $*$ & $?$ & $?$ & - & $?$ \\
\hline
\end{tabular}

Key: ${ }^{* * *}$, major; ${ }^{* *}$, medium; ${ }^{*}$,minor; -,nil or not applicable 


\begin{tabular}{|c|c|c|c|}
\hline Mechanism & $\begin{array}{l}\text { potential } \\
\text { environmental } \\
\text { significance }\end{array}$ & $\begin{array}{l}\text { how } \\
\text { widespread in } \\
\text { ecotourism } \\
\text { sector }\end{array}$ & $\begin{array}{l}\text { severity } \\
\text { of net } \\
\text { effects }\end{array}$ \\
\hline $\begin{array}{l}\text { Increased longhaul travel and associated } \\
\text { climate change effects }\end{array}$ & $* * *$ & $* *$ & $* *$ \\
\hline Direct environmental impacts & $* *$ & $* * *$ & * \\
\hline Entrée for high-impact tourism & $* *$ & $* *$ & $*$ \\
\hline $\begin{array}{l}\text { Excuse for development where not } \\
\text { otherwise permitted }\end{array}$ & $* *$ & $* *$ & * \\
\hline $\begin{array}{l}\text { "Partnerships" with parks agencies } \\
\text { where tour operator pretends to provide } \\
\text { net gains for conservation but in fact } \\
\text { generates net costs }\end{array}$ & $*$ & $* *$ & $*$ \\
\hline $\begin{array}{l}\text { "Ecotourism lite” which masquerades as } \\
\text { low-impact but in fact has severe } \\
\text { negative environmental effects. }\end{array}$ & $*$ & $* * *$ & $*$ \\
\hline $\begin{array}{l}\text { Undeserved ecotourism awards which } \\
\text { provide erroneous marketing } \\
\text { information }\end{array}$ & * & $*$ & $*$ \\
\hline
\end{tabular}

Key: ***, major; ${ }^{* *}$, medium; *, minor; -, nil or not applicable 


\begin{tabular}{|c|c|c|}
\hline Issue & Position A & Position B \\
\hline $\begin{array}{l}\text { Scale and } \\
\text { mainstreaming }\end{array}$ & $\begin{array}{l}\text { Small scale is a defining } \\
\text { criterion for ecotourism; small is } \\
\text { beautiful, big is bad; ecotourism } \\
\text { is fundamentally different from } \\
\text { mainstream tourism. }\end{array}$ & $\begin{array}{l}\text { Ecotourism cannot have any } \\
\text { significant global influence unless } \\
\text { it becomes mainstream and/or } \\
\text { large-scale and/or changes } \\
\text { mainstream tourism practices }\end{array}$ \\
\hline $\begin{array}{l}\text { Local } \\
\text { empowerment }\end{array}$ & $\begin{array}{l}\text { Local empowerment is itself one } \\
\text { of the goals and/or defining } \\
\text { criteria of ecotourism and should } \\
\text { always be pursued. This } \\
\text { includes local control of } \\
\text { protected areas and other land as } \\
\text { well as local ownership of } \\
\text { enterprises and local monopoly } \\
\text { on craft and guiding rights. }\end{array}$ & $\begin{array}{l}\text { Local empowerment is one } \\
\text { mechanism which may under } \\
\text { some circumstances lead to more } \\
\text { effective conservation of } \\
\text { biodiversity, and is significant to } \\
\text { ecotourism only through this } \\
\text { mechanism. }\end{array}$ \\
\hline
\end{tabular}

$\begin{array}{ll}\text { Poverty } & \text { Alleviating poverty is itself a } \\ \text { alleviation } & \text { key goal or defining criterion of } \\ & \text { ecotourism, at least as } \\ & \text { significant as environmental } \\ & \text { criteria. }\end{array}$

Public-private Partnership is a politically partnerships plausible term used by tourism property developers to gain preferential access to public parks resources at rates well below their market value, with no net gain for conservation.

Ecocertification
Eco-certification allows tourists to select products or enterprises where environmental performance is externally certified.
Alleviation of poverty is a valid goal in itself but is not per se a defining criterion or goal of ecotourism. It is simply one mechanism which may make either a positive or negative net contribution to the environmental goals which define ecotourism.

There are some limited circumstances where parks agencies can cut costs or generate revenue by contracting the operation of certain visitor facilities to private corporations, as long as these operations are in line with parks management priorities, and commercial arrangements are equitable for the parks agency and independent visitors as well as the private company.

Eco-certification is ineffective at distinguishing superior environmental performance, has been co-opted as a marketing ploy, and is largely ignored by both customers and regulators. 
Long-haul travel
The environmental impacts of ecotourism include those of travel to the ecotourism site, so ecotourism should focus only on local clientele.
The greatest environmental gains through ecotourism rely on bringing wealthy clients from developed nations to visit conservation areas in developing nations, and contributions to global conservation outweigh the contributions to global climate change. 
Figure 1

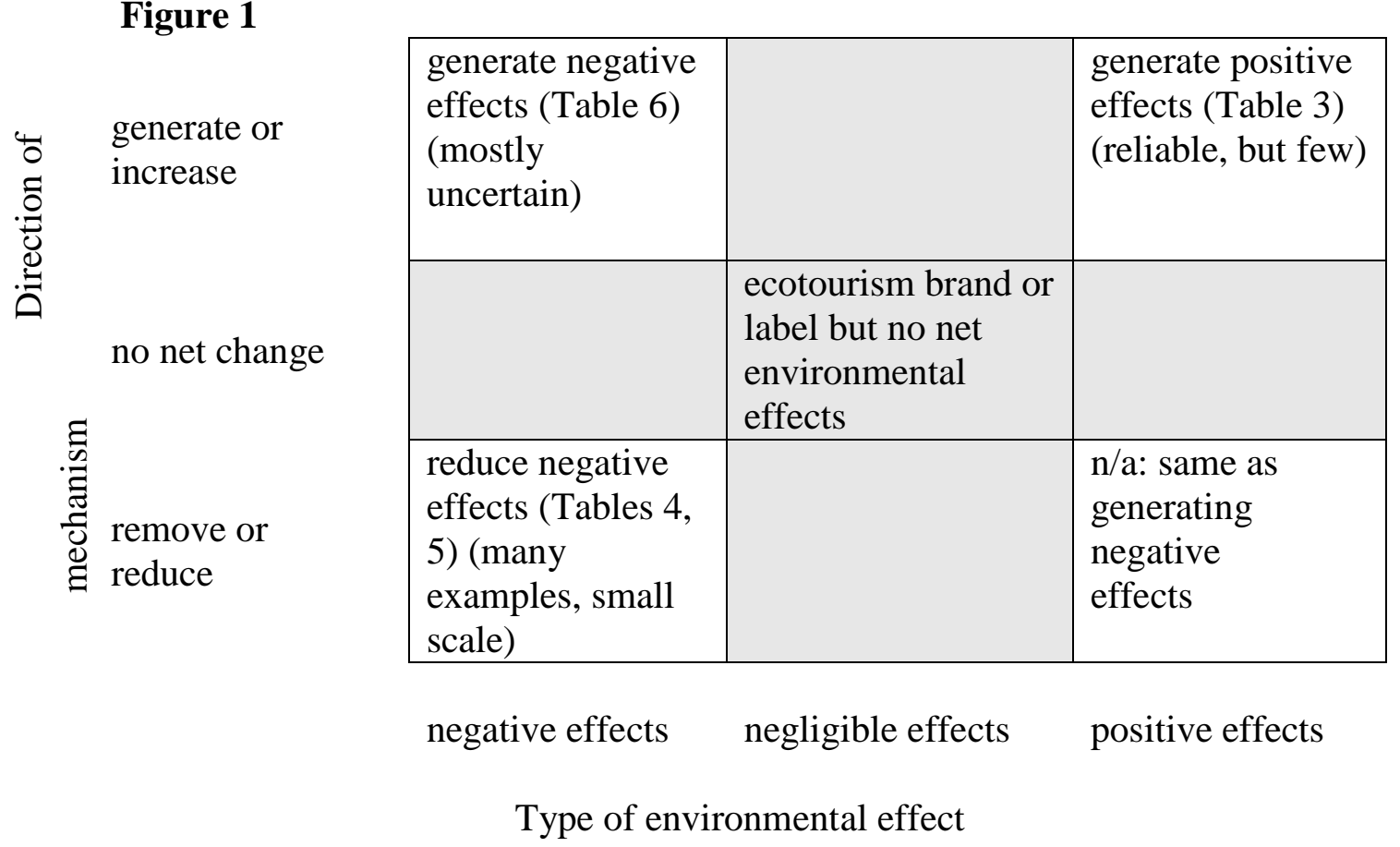

This figure illustrates that the mechanisms discussed here, positive or negative, may represent only small components in a broad matrix of little effect. 
Figure 2 Relative Scale of Various Mechanisms

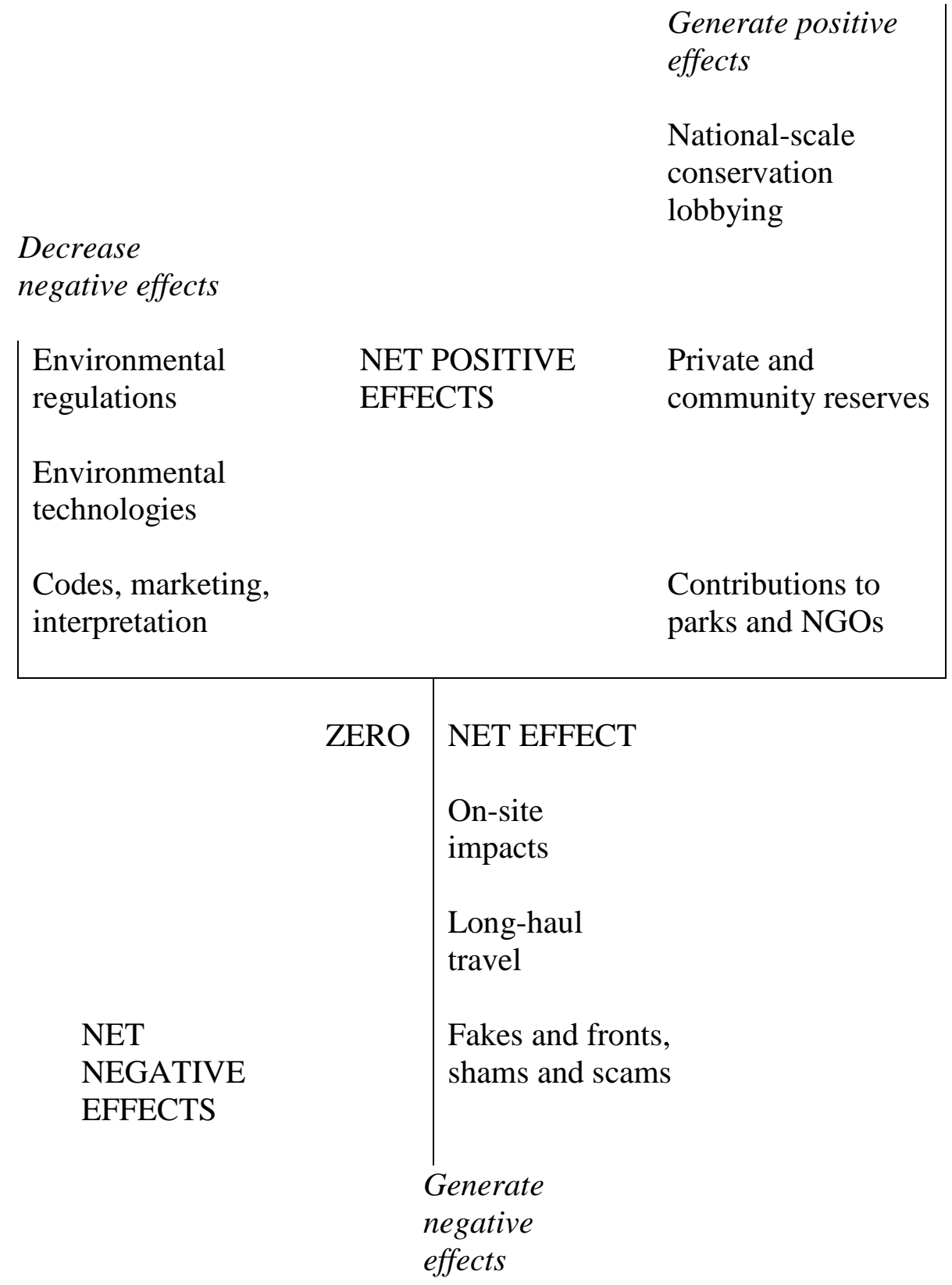

Note: in general, the mechanisms which potentially produce the largest effects are also the most uncertain 


\section{References}

\&Beyond (2009) http://www.andbeyond.com/ Accessed 19.1.09.

Alexander, S.E. (2000) Resident attitudes towards conservation and black howler monkeys in Belize: The Community Baboon Sanctuary. Environmental Conservation 27, 341-350.

ANGAP-PNM (2009) Parcs Nationaux Madagascar http://www.parcs-madagascar.com Accessed 27.1.09.

Barkin, D. (2003) Alleviating poverty through ecotourism: Promises and reality in the monarch butterfly reserve of Mexico. Environment, Development and Sustainability 5, 371-382.

Barnes, J.I. (2008) Community-based tourism and natural resource management in Namibia: Local and national economical impacts. In A. Spenceley (ed.) Responsible Tourism: Critical Issues for Conservation and Development (pp. 343-360). London: Earthscan.

Bauer, T. (1997) Commercial tourism in the Antarctic: Trends, opportunities, constraints and regulation. PhD thesis, Monash University, Melbourne.

Beaumont, N. (2001) Ecotourism and the conservation ethic: Recruiting the uninitiated or preaching to the converted? Journal of Sustainable Tourism 9, 317-341.

Becken, S. and Hay, J. (2007) Tourism and Climate Change: Risks and Opportunities. Clevedon: Channel View Publications.

Becken, S. and Simmons, D.G. (2002) Understanding energy consumption patterns of tourism attractions and activities in New Zealand. Tourism Management 23, 343-354.

Beedie, P. (2003). Mountain guiding and adventure tourism: Reflections on the choreography of the experience. Leisure Studies 22 (2), 147-167.

Belsky, J.M. (1999) Misrepresenting communities: The politics of community-based rural ecotourism in Gales Point Manatee, Belize. Rural Sociology 64, 641-666.

Black, R. and Crabtree, A. (2007) Quality Control and Certification in Ecotourism. Wallingford: CAB International.

Borman, R. (2008) Ecotourism and conservation: The Cofan experience. In A. Stronza and H. Durham (eds) Ecotourism and Conservation in the Americas (pp. 21-29). Wallingford: CAB International.

Bowerman, K. (2008) Part 2. In Pellegrini, T. Fast Track, Week 44. BBC News, London. 
Bramwell, B. and Lane, B. (2008) Editorial: Priorities in sustainable tourism research. Journal of Sustainable Tourism 16, 1-4.

Brightsmith, D.J., Stronza, A. and Holle, K. (2008) Ecotourism, conservation biology and volunteer tourism: A mutually beneficial triumvirate. Biological Conservation 141, 2832-2842.

Broderick, J. (2009) Voluntary carbon offsets: a contribution to sustainable tourism? In S. Gössling, C. Hall, and D. Weaver (eds) Sustainable Tourism Futures (pp. 169-199). New York: Routledge.

Buckley, R.C. (2002a) Minimal-impact guidelines for mountain ecotours. Tourism Recreation Research 27 (3), 35-40.

Buckley, R. (2002b) Tourism eco-certification in the International Year of Ecotourism. Journal of Ecotourism 1, 197-203.

Buckley, R.C. (2003a) Case Studies in Ecotourism. Wallingford: CAB International, 264 pp.

Buckley, R.C. (2003b) Pay to play in parks: an Australian policy perspective on visitor fees in public protected areas. Journal of Sustainable Tourism 11, 56-73.

Buckley, R.C. (2003c) Environmental inputs and outputs in ecotourism: geotourism with a positive triple bottom line? Journal of Ecotourism 2, 76-82.

Buckley, R.C. (ed.) (2004a) Environmental Impacts of Ecotourism. Wallingford: CAB International, $389 \mathrm{pp}$.

Buckley, R.C. (2004b) Partnerships in ecotourism: Australian political frameworks. International Journal of Tourism Research 6, 75-83.

Buckley, R.C. (2005) In search of the narwhal: ethical dilemmas in ecotourism. Journal of Ecotourism 4, 129-134.

Buckley, R.C. (2006) Adventure Tourism. Wallingford: CAB International, 528 pp.

Buckley, R.C. (2008a) World Wild Web: Funding connectivity conservation under climate change. Biodiversity 9 (3 and 4), 71-78.

Buckley, R.C. (2008b) Tourism as a conservation tool. In A. Raschi and S. Trampetti (eds) Management for Protection and Sustainable Development (pp. 19-25). Consiglio Nationale della Ricerche, Montecatini, Italy.

Buckley, R.C. (2009) Ecotourism: Principles and Practices. Wallingford: CAB International, $368 \mathrm{pp}$.

Buckley, R. and Littlefair, C. (2007) Minimal-impact education can reduce actual impacts of park visitors. Journal of Sustainable Tourism 15, 324-325. 
Bushell, R. and Eagles, P. (eds) (2007) Tourism And Protected Areas: Benefits Beyond Boundaries: The Vth IUCN World Parks Congress. Wallingford: CAB International, p. 349.

Byrnes, T.A. and Warnken, J. (2006) Greenhouse gas emissions from marine tours: A case study of Australian tour boat operators. Journal of Sustainable Tourism 14, 255270.

Campbell, L. (2007) Local conservation practice and global discourse: A political ecology of sea turtle conservation. Annals of the Association of American Geographers 97, 313-334.

Carlisle, L. (2007) Conservation and community development: The Conservation Corporation Africa model. In R. Bushell and P.J.F. Eagles (eds) Tourism and Protected Areas: Benefits Beyond Boundaries (pp. 244-265). Wallingford: CAB International.

Cater, C. and Cater, E. (2007) Marine Ecotourism: Between the Devil and the Deep Blue Sea. Wallingford: CAB International, 307 pp.

Ceron, J. and Dubois, G. (2009) Tourism and climate change mitigation: Which data is needed for what use? In S. Gössling, C. Hall, and D. Weaver (eds) Sustainable Tourism Futures (pp. 84-101). New York: Routledge.

Chase, L.C., Lee, D.R., Schulze, W.D. and Anderson, D.J. (1998) Ecotourism demand and the differential pricing of national park access in Costa Rica. Land Economics 74, 466.

Clarke, J.E. (2001) An Evaluation of the Cullman and Hurt Community Wildlife Project, Tanzania. Report to CHCWP, Exmouth, UK, 30 pp.

Conservation International (2009) Discover, Learn, Explore, Act, Give http://www.conservation.org/Pages/default.aspx Accessed 19.1.09.

Cristalino Jungle Lodge (2009) An Amazon Sanctuary.

http://www.cristalinolodge.com.br/index_cristalino-jungle-lodge.htm Accessed 19.1.09.

Diamantis, D. (ed.) (2004) Ecotourism: Management and Assessment. London: Thomson Learning.

Donohoe, H.M. and Needham, R.D. (2006) Ecotourism: The evolving contemporary definition. Journal of Ecotourism 5, 192-210.

Eagles, P.F.J. (2002) Trends in park tourism: Economics, finance and management. Journal of Sustainable Tourism 10, 132-153.

Eagles and McCool (2002) Sustainable Tourism in Protected Areas. Guidelines for Planning and Management. IUCN WCPA Best Practice Series No 8. Gland, Switzerland: IUCN. 
Ezaki, A. (2009) ecoDestinations. Posting on 30 Jan 2009 by The International Ecotourism Society to the Facebook group Your Travel Choice Makes a Difference, started by TIES. http://facebook.com/group.php Accessed 30.01.09

Fennell, D. (1999) Ecotourism: An Introduction. New York: Routledge.

Fennell, D. and Dowling, R. (2003) Ecotourism Policy and Planning. Wallingford: CAB International.

Fennell, D. and Malloy, D. (2007) Codes of Ethics in Tourism. Cleveland: Channel View Publications.

Figgis, P. and Bushell, R. (2007) Tourism as a tool for community-based conservation and development. In R. Bushell and P.J.F. Eagles (eds) Tourism and Protected Areas: Benefits Beyond Boundaries (pp. 101-114). Wallingford: CAB International.

Folke, J., Hammer Ostrup, J. and Gössling, S. (2006) Ecotourist choices of transport modes. In S. Gössling and J. Hultman Ecotourism in Scandinavia: Lessons in Theory and Practice (pp. 154-165). Wallingford: CAB International.

Font, X. and Buckley, R.C. (eds) (2001) Tourism Eco-labelling. Wallingford: CAB International, 359 pp.

Font, X., Sanabria, R. and Skinner, E. (2003) Sustainable tourism and ecotourism certification: Raising standards and benefits. Journal of Ecotourism 2, 213-218.

Garrod, B. and Fennell, D.A. (2004) An analysis of whalewatching codes of conduct. Annals of Tourism Research 31, 334-352.

Godde, P.M., Price, M.F. and Zimmermann, F.M. (eds) (2000) Tourism and Development in Mountain Regions. New York: CAB International.

Gordillo Jordan, J.F., Hunt, C. and Stronza, A. (2008) An ecotourism partnership in the Peruvian Amazon: The case of Posada Amazonas. In A. Stronza and H. Durham (eds) Ecotourism and Conservation in the Americas (pp.30-48). Wallingford: CAB International.

Gössling, S., Hall, C.M., Lane, B. and Weaver, D. (2008) The Helsingborg statement on sustainable tourism. Journal of Sustainable Tourism 16, 122-124.

Gössling, S., Hall, C.M. and Weaver, D. (2009) Sustainable Tourism Futures. London: Routledge.

Gössling, S. and Hultman, J. (2006) Ecotourism in Scandinavia: Lessons in Theory and Practice. Wallingford: CAB International.

Great Barrier Reef Marine Park Authority (GBRMPA) (2008) The Gateway for Information about the Great Barrier Reef and World Heritage Area. http://www.gbrmpa.gov.au/ Accessed 9.1.09. 
Grieves-Cook, J. (2002) Eselenkei Conservation Area. In WTO (comp.) Sustainable Development of Ecotourism: A Compilation of Good Practices (pp. 163-165). Madrid: World Tourism Organisation.

Gurung, H. (2008) Fusioning: A grounded theory of participatory governance in the Annapurna Conservation Area, Nepal. PhD thesis, Griffith University, Gold Coast, Australia.

Hall, C.M. and Boyd, S.W. (2005) Nature-based Tourism in Peripheral Areas: Development or Disaster? Clevedon: Channel View Publications.

Hall, C.M. and Higham, J. (2005) Tourism, Recreation and Climate Change. Clevedon: Channel View Publications.

Hall, C.M. and Lew, A.A. (1998) Sustainable Tourism: A Geographical Perspective. New York: Longman.

Hammitt, W. and Cole, D. (1998) Wildland Recreation: Ecology and Management, $\left(2^{\text {nd }}\right.$ edn). New York: John Wiley.

Harrison, D. (2001) Tourism and the Less Developed World: Issues and Case Studies. Wallingford: CAB International.

Hawkins, D.E., Epler Wood, M. and Bittman, S. (1995) The Ecolodge Sourcebook for Planners and Developers. North Bennington, VT: The Ecotourism Society.

Hendee, J.C. and Dawson, C.P. (2002) Wilderness Management, (3 ${ }^{\text {rd }}$ edn). Fulcrum: Golden.

Higham, J.E.S. and Luck, M. (2008) Marine Wildlife and Tourism Management. Wallingford, CAB International.

Honey, M. (1999) Ecotourism and Sustainable Development: Who Owns Paradise? Washington, D.C.: Island Press.

Honey, M. (2002) Ecotourism and Certification: Setting Standards in Practice. Washington, DC: Island Press.

Ingram, C. (2007) Certification in protected areas: A Western Australian case study. In R. Black and A. Crabtree (eds) Quality Assurance and Certification in Ecotourism (pp. 266-298). Wallingford: CAB International.

Jacobi, C. (2003) An Experiment Using Signs to Reduce Visitor-Built Cairns in Acadia National Park. ANP Natural Resource Reports 2002-04. Bar Harbor, M.E.: USDI National Park Services.

Kohl, J. (2007) Putting the ecotour guide back into context: using systems thinking to develop quality guides. In R. Black and A. Crabtree (eds) Quality Assurance and Certification in Ecotourism (pp. 337-363). Wallingford: CAB International. 
Kohl, J. (2008) Environmental interpretation versus environmental education as an ecotourism conservation strategy. In A. Stronza and H. Durham (eds) Ecotourism and Conservation in the Americas (pp. 127-140). Wallingford: CAB International.

Kruger, O. (2005) The role of ecotourism in conservation: Panacea or Pandora's box? Biodiversity and Conservation 14, 579-600.

Liddle, M.J. (1997) Recreation Ecology: The Ecological Impact of Outdoor Recreation. Dordrecht: Kluwer Academic Publishers.

Lindberg, K. and Aylward, B. (1999) Price responsiveness in the developing country nature tourism context: Review and Costa Rican case study. Journal of Leisure Research 31, 281-299.

Lindberg, K., Enriquez, J. and Sproule, K. (1996) Ecotourism questioned: Case studies from Belize. Annals of Tourism Research 23, 543-562.

Littlefair, C. (2004) Reducing impacts through interpretation, Lamington National Park. In R.C. Buckley (ed.) Environmental Impacts of Ecotourism (pp. 297-308). Wallingford: CAB International.

Littlefair, C. and Buckley, R. (2008) Interpretation reduces ecological impacts of visitors to World Heritage Areas. Ambio 37, 338-341.

Lockwood, M., Worboys, G. and Kothari, A. (2006) Managing Protected Areas: A Global Guide. London: Earthscan.

Loon, R., Harper, I. and Shorten, P. (2007) Sabi Sabi: A model for effective ecotourism, conservation and community involvement. In R. Bushell and P.J.F. Eagles (eds) Tourism and Protected Areas: Benefits Beyond Boundaries (pp. 264-276). Wallingford: CAB International.

Lück, M. and Kirstges, T. (2003) Global Ecotourism Policies and Case Studies: Perspectives and Constraints. Clevedon: Channel View Publications.

McCool, S. and Moisey, R. (2001) Tourism, Recreation and Sustainability: Linking Culture and the Environment. New York: CAB International.

McKercher, B. (1998) The Business of Nature-Based Tourism. Melbourne: Hospitality Press, 220 pp.

McLaren, D. (1998) Rethinking Tourism and Ecotravel: The Paving of Paradise and What You Can Do To Stop It. West Hartford: Kumarian Press.

Manning, R.E. (2007) Parks and Carrying Capacity: Commons Without Tragedy. Washington: Island Press.

Manning, T. (1999) Indicators of tourism sustainability. Tourism Management 20, 179181. 
Marion, J.L. and Reid, S.E. (2007) Minimising visitor impacts to protected areas: The efficacy of low impact education programmes. Journal of Sustainable Tourism 15, 5-27.

Mason, P. (2007) 'No better than a band-aid for a bullet wound!': The effectiveness of tourism codes of conduct. In R. Black, and A. Crabtree (eds) Quality Assurance and Certification in Ecotourism (pp. 46-64). Wallingford: CAB International.

Massyn, P.J. (2008) Citizen participation in the lodge sector of the Okavango Delta. In A. Spenceley (ed.) Responsible Tourism: Critical Issues for Conservation and Development (pp. 225-238). London: Earthscan.

Medio, D., Ormond, R.F.G. and Pearson, M. (1997) Effect of briefings on rates of damage to corals by scuba divers. Biological Conservation 79, 91-94.

Mehta, H. (2007) Towards an internationally recognised ecolodge certification. In R. Black, and A. Crabtree. Quality Assurance and Certification in Ecotourism (pp. 415434). Wallingford: CAB International.

Mowforth, M. and Munt, I. (2003) Tourism and Sustainability ( $2^{\text {nd }}$ edn). London: Routledge.

Nelson, F. (2008) Livelihoods, conservation and community-based tourism in Tanzania: Potential and performance. In A. Spenceley (ed.) Responsible Tourism: Critical Issues for Conservation and Development (pp. 305-322). London: Earthscan.

Nevard, T. (2005) The Mareeba Wetlands: Planning for wildlife management through tourism. In R. Buckley (ed.) Tourism in Parks: Australian Initiatives. (pp. 175-184). Australia: Griffith University.

Newsome, D., Moore, S. and Dowling, R. (2002) Natural Areas Tourism: Ecology, Impacts and Management. Clevedon: Channel View.

Nycander, E. (2002) Posada Amazonas: un proyecto ecoturistito en el Parque Nacional Bahuaja-Sonene. In WTO (comp) Sustainable Development of Ecotourism: A Compilation of Good Practices (pp. 197-199). Madrid: World Tourism Organization.

Oliver, S.S., Roggenbuck, J.W. and Watson, A.E. (1985) Education to reduce impacts in forest campgrounds. Journal of Forestry 83, 234-236.

Ostergren, D., Solop, F.I. and Hagen, K.K. (2005) National park services fees: Value for the money or a barrier to visitation? Journal of Park and Recreation Administration 23, 18-36.

Pawliczek, M. and Mehta, H. (2008) Ecotourism in Madagascar: How a sleeping beauty is finally awakening. In A. Spenceley (ed.) Responsible Tourism: Critical Issues for Conservation and Development (pp. 41-68). London: Earthscan.

Peeters, P., Gössling, S. and Lane, B. (2009) Moving towards low-carbon tourism: New opportunities for destinations and tour operators. In S. Gössling, C. Hall, and D. Weaver (eds) Sustainable Tourism Futures (pp. 240-257). New York: Routledge. 
Pigram, J.J. and Jenkins, J.M. (2006) Outdoor Recreation Management. London: Routledge.

Pleumarom, A. (1993) What's wrong with mass ecotourism. Contours Bangkok 6, 1521.

Prideaux, B. and Cooper, M. (eds) (2009) River Tourism. Wallingford: CAB International.

Rainforest Alliance (2009) Innovative Solutions for Global Conservation. http://www.rainforest-alliance.org/ Accessed 9.1.09.

Raschi, A. and Trampetti, S. (eds) (2008) Management for Protection and Sustainable Development. Consiglio Nationale della Ricerche: Montecatini, Italy.

Relly, P. (2008) Madikwe Game Reserve, South Africa - investment and employment. In A. Spenceley (ed.) Responsible Tourism: Critical Issues for Conservation and Development (pp. 267-284). London: Earthscan.

Repoblikan'i Madagasikara (2009) Ministère de l'Environnement, des Forêts et du Tourisme, Destination Madagascar, Parcs nationaux et circuits. http://www.meeft.gov.mg Accessed 27.1.09.

Rijal, A. (1997) The Baghmara community forest: an example of linkages between community forestry and ecotourism. In J. Bornemeier, M. Victor and P. Durst (eds) Ecotourism for Forest Conservation and Community Development (pp. 144-159). Chiang Mai: FAO/RAP Publication 97/26.

Roggenbuck, J.W. and Berrier, D.L. (1982) A comparison of the effectiveness of two communication strategies in dispersing wilderness campers. Journal of Leisure Research 14, 77-89.

Rome, A. (2007) Quality in ecotourism: the community perspective. In R. Black and A. Crabtree (eds) Quality Assurance and Certification in Ecotourism (pp. 196-217). Wallingford: CAB International.

Rowe, T. and Higham, J. (2007) Ecotourism certification in New Zealand: operator and industry perspectives. In R. Black and A. Crabtree (eds) Quality Assurance and Certification in Ecotourism (pp. 395-414). Wallingford: CAB International.

Salafsky, N., Cauley, H., Balachander, G., Cordes, B., Parks, J., Margoluis, C., Bhatt, S., Encarnacion, C., Russell, D. and Margoluis, R. (2001) A systematic test of an enterprise strategy for community-based biodiversity conservation. Conservation Biology 15(6), 1585-1595.

Salafsky, N. and Wollenberg, E. (2000) Linking livelihoods and conservation: A conceptual framework and scale for assessing the integration of human needs and biodiversity. World Development 28, 1421-1438. 
Scarpaci, C. and Dayanthi, N. (2003) Compliance with regulations by swim-withdolphins operations in Port Phillip Bay, Victoria, Australia. Environmental Management 31, 342-347.

Schmiechen, J. (2002) The Manyallaluk experience.

http://www.aboriginalaustralia.com.au/microsites/site/manyallaluk.htm Accessed 19.1.09.

Seacology (2009) Seacology is an international environmental nonprofit organization that focuses on saving endangered species, habitats and cultures of islands throughout the world http://www.seacology.org/ Accessed 19.1.09.

Shah, N.J. (2002) A success story in the Seychelles. National Park International Bulletin 5, 1-4.

Singh, T.V. (ed.) (2004) New Horizons in Tourism. Wallingford: CAB International.

Snyder, J., and Stonehouse, B. (2007) (eds) Prospects for Polar Tourism. Wallingford: CAB International, $318 \mathrm{pp}$.

Spenceley, A. (2008a) Responsible Tourism: Critical Issues for Conservation and Development. London: Earthscan, 432 pp.

Spenceley, A. (2008b) Impacts of wildlife tourism on rural livelihoods in southern Africa. In A. Spenceley (ed.) Responsible Tourism: Critical Issues for Conservation and Development (pp.159-186). London: Earthscan.

Sproule, K.W. and Suhandi, A.S. (1998) Guidelines for community based ecotourism programs. In K. Lindberg, M. Epler-Wood and D. Ingeldrum (eds) Ecotourism: A Guide for Planners and Managers (pp. 215-235). North Bennington, Vermont: Ecotourism Society.

Stabler, M. J. (ed.) (1997) Tourism and Sustainability: Principles to Practice. Wallingford: CAB International, $380 \mathrm{pp}$.

Stronza, A. and Durham, W.H. (eds) (2008) Ecotourism and Conservation in the Americas. Wallingford: CAB International.

Sukau Rainforest Lodge (2009) http://www.sukau.com/ Accessed 20.1.09.

The Nature Conservancy (2009) Protecting Nature, Preserving Life. . http://nature.org Accessed 30.1.09.

UNEP Tour Operators' Initiative for Sustainable Tourism Development (2003) Sustainable Tourism: the Tour Operators Contribution. UNEP: Paris.

Varghese, G. (2008) Public-private partnerships in South African national parks: The rationale, benefits and lessons learned. In A. Spenceley (ed.) Responsible Tourism: Critical Issues for Conservation and Development (pp. 69-84). London: Earthscan. 
Varty, S. and Buchanan, M. (1999) The Return: The Story of Phinda Game Reserve. Rivonia: Londolozi Publishers.

Vasconcellos-Pêgas, F. and Stronza, A. (2008) Ecotourism equations: Do economic benefits equal conservation? In A. Stronza and H. Durham (eds) Ecotourism and Conservation in the Americas (pp. 163-176). Wallingford: CAB International.

Vereczi, G. (2007) Sustainability indicators for ecotourism destinations and operations. In R. Black and A. Crabtree (eds) Quality Assurance and Certification in Ecotourism (pp. 101-115). Wallingford: CAB International.

Waayers, D., Newsome, D. and Lee, D. (2006) Research note observations of noncompliance behaviour by tourists to a voluntary code of conduct: A pilot study of turtle tourism in the Exmouth region, Western Australia. Journal of Ecotourism 5, 211-222.

Walpole, M.J., Goodwin, H.J. and Ward, G.R. (2001) Pricing policy for tourism in protected areas: Lessons from Komodo National Park, Indonesia. Conservation Biology $15,218-227$.

Weaver, D. (1998) Ecotourism in the Less Developed World. Wallingford: CAB International.

Weaver, D. (2001) The Encyclopedia of Ecotourism. Wallingford: CAB International, $688 \mathrm{pp}$.

Weaver, D. (2006) Sustainable Tourism: Theory and Practice. Oxford: Elsevier.

Weaver, D. (2008) Ecotourism ( $2^{\text {nd }}$ edn) Milton: Wiley.

Weaver, D.B. and Lawton, L.J. (2007) Twenty years on: The state of contemporary ecotourism research. Tourism Management 28, 1168-1179.

Wheeller, B. (1997) Here we go, here we go, here we go eco. In M.J. Stabler (ed.) Tourism and Sustainability: Principles to Practice (pp. 39-50). Wallingford: CAB International.

Widner, C.J. and Roggenbuck, J.W. (2000) Reducing theft of petrified wood at Petrified Forest National Park. Journal of Interpretation Research 5, 1-18.

Wilderness Safaris (2009) Our Journeys Change People's Lives. http://www.wilderness-safaris.com/ Accessed 19.1.09.

Wiley, D.N., Moller, J.C., Pace III, R.M. and Carlson, C. (2008) Effectiveness of voluntary conservation agreements: Case study of endangered whales and commercial whale watching. Conservation Biology 22, 450-457.

Wunder, S. (2000) Ecotourism and economic incentives - an empirical approach. Ecological Economics 32, 465-479. 
Zeppel, H. (1998) Land and culture: Sustainable tourism and Indigenous peoples. In C.M. Hall and A.A. Lew (eds) Sustainable Tourism: A Geographic Perspective (pp. 6074). Harlow: Longman. 